\title{
Labor in the Twenty-First Century: The Top 0.1\% and the Disappearing Middle-Class
}

\author{
William Lazonick $*$
}

\author{
Working Paper No. 4
}

\author{
February 2015
}

\begin{abstract}
The ongoing explosion of the incomes of the richest households and the erosion of middle-class employment opportunities for most of the rest have become integrally related in the now-normal operation of the U.S. economy. Since the beginning of the 1980s, employment relations in U.S. industrial corporations have undergone three major structural changes - summarized as "rationalization," "marketization," and "globalization" - that have permanently eliminated middle-class jobs in the United States. From the early 1980s, rationalization, characterized by plant closings, terminated the jobs of high-school educated blue-collar workers, most of them well-paid union members. From the early 1990s, marketization, characterized by the end of a career with one company as an employment norm, placed the job security of middle-aged whitecollar workers, many of them college educated, in jeopardy. From the early 2000s, globalization, characterized by the movement of employment offshore to lower-wage nations, left all members of the U.S. labor force, whatever their educational credentials and work experience, vulnerable to displacement. Initially, these structural changes in employment could be justified as business responses to changes in technologies, markets, and competitors. Once U.S. corporations transformed their employment relations, however, they often pursued rationalization, marketization, and globalization to cut current costs rather than to reposition themselves to produce competitive products. Defining superior corporate performance as ever-higher quarterly earnings per share, companies turned to massive stock repurchases to "manage" their own corporations' stock prices. Trillions of dollars that could have been spent on innovation and job creation in the U.S. economy over the past three decades have instead been used to buy back
\end{abstract}

\footnotetext{
*William Lazonick: University of Massachusetts Lowell and The Academic-Industry Research Network. william.lazonick@gmail.com
} 
stock for the purpose of manipulating stock prices. Legitimizing this financialized mode of corporate resource allocation has been the ideology, itself a product of the 1980s and 1990s, that a business corporation should be run to "maximize shareholder value." Through their stock options and stock awards, corporate executives who make these resource-allocation decisions are themselves prime beneficiaries of the focus on rising stock prices as the sole measure of corporate performance. While rationalization, marketization, and globalization undermined stable and remunerative employment structures, the "financialization" of the U.S. corporation entailed the distribution of corporate cash to shareholders through stock repurchases, often in addition to generous cash dividends, and, incentivizing these distributions, the stock-based remuneration of top corporate executives. In this essay, I review evidence on the fundamental structural changes related to rationalization, marketization, and globalization that, since the early 1980s, have eroded U.S. middle-class employment opportunities. Then, I analyze how, in many different ways and in many different industries, the financialized mode of corporate resource allocation has undermined the prosperity of the U.S. economy. I go on to show how justified by the ideology that companies should be run to "maximize shareholder value," this financialized behavior boosts the remuneration of top corporate executives, providing a major explanation for the increasing concentration of income among the top $0.1 \%$ of U.S. households that is, through the very way it is achieved, based on the systematic destruction of middle-class employment opportunities available to members of the U.S. labor force.

JEL Codes: D22, D31, G35, G38, J53, L21, M12, M21, N82, O30, P12

A version of this paper will appear in Christian E. Weller, ed. Financial Market Developments and Labor Relations, Labor and Employment Relations Association, 2015. This paper builds on research and ideas in a number of my published papers including "The Financialization of the U.S. Corporation," Seattle University Law Review, 36, 2013: 857-909; "Innovative Enterprise and Shareholder Value," Law and Financial Markets Review, 8, 1, 2014: 52-64; "Taking Stock: Why Executive Pay Results in an Unstable and Inequitable Economy," Roosevelt Institute White Paper, June 5, 2014; and "Profits Without Prosperity: Stock Buybacks Manipulate the Market and Leave Most Americans Worse Off," Harvard Business Review, September 2014: 46-55; as well as on my book, Sustainable Prosperity in the New Economy? Business Organization and High-Tech Employment in the United States, Upjohn Institute for Employment Research, 2009.

The research in this paper has been funded by the Institute for New Economic Thinking (INET) projects on "The Stock Market and Innovative Enterprise" and "Impatient Capital in High-Tech Industries"; the Ford Foundation project on "Financial Institutions for Innovation and Development"; and the European Commission project on "Finance, Innovation, and Growth." Mustafa Erdem Sakinç has coordinated the development and maintenance of the stock-buyback database, and Dongxu Li, Qiaoling Ma, Xiahui Xia, and Yue Zhang have provided research assistance. I am grateful to Tom Ferguson, Matt Hopkins, Ken Jacobson, Phil Moss, Lynn Parramore, Hal Salzman, and Öner Tulum for discussions on the issues treated in this paper, as well as to Justin Fox and Steve Prokesch of Harvard Business Review for probing questions in the process of writing the HBR article, "Profits Without Prosperity." Also I would like to thank Ken Jacobson for proofreading and editorial comments. 


\section{Where Have All the Good Jobs Gone?}

Over the past four decades real GDP per capita has about doubled in the United States. Yet most Americans are not all that better off. The ongoing explosion of the incomes of the richest households and the erosion of middle-class employment opportunities for most of the rest raise serious questions about whether the U.S. economy is beset by deep structural problems. My research on the evolution of the U.S. economy over the past half-century shows that a structural explanation is indeed warranted. ${ }^{1}$

Since the beginning of the 1980s, employment relations in U.S. industrial corporations have undergone three major structural changes - which I summarize as "rationalization," "marketization," and "globalization" - that have permanently eliminated middle-class jobs in the United States. From the early 1980s, rationalization, characterized by plant closings, terminated the jobs of high-school-educated blue-collar workers, most of them well-paid union members. From the early 1990s, marketization, characterized by the end of a career with one company as an employment norm, placed the job security of middle-aged white-collar workers, many of them college educated, in jeopardy. From the early 2000s, globalization, characterized by the movement of employment offshore to lower-wage areas of the world, left all members of the U.S. labor force, even those with advanced educational credentials and substantial work experience, vulnerable to displacement.

Initially, each of these structural changes in employment could be justified as a business response to major changes in industrial conditions related to technologies, markets, and competitors. During the onset of the rationalization phase in the early 1980s, the plant closings were a reaction to the superior productive capabilities of Japanese competitors in consumerdurable and related capital-goods industries that employed significant numbers of unionized blue-collar workers. ${ }^{2}$ During the onset of the marketization phase in the early 1990s, the erosion of the one-company-career norm among white-collar workers was a response to the dramatic technological shift from proprietary systems to open systems, integral to the microelectronics revolution. This shift favored younger workers with the latest computer skills, acquired in higher education and transferable across companies, over older workers with many years of companyspecific experience with systems integration. ${ }^{3}$ During the onset of the globalization phase in the early 2000s, the sharp acceleration in the offshoring of jobs was a response to the emergence of large supplies of highly capable, and lower wage, labor in developing nations such as China and India which, linked to the United States through inexpensive communications systems, could take over U.S. employment activities that had become routine. ${ }^{4}$

Once U.S. corporations transformed their employment relations, however, they often pursued rationalization, marketization, and globalization to cut current costs rather than to reposition themselves to produce competitive products. That is, they closed manufacturing plants,

\footnotetext{
${ }^{1}$ William Lazonick, Sustainable Prosperity in the New Economy? Business Organization and High-Tech Employment in the United States, Upjohn Institute for Employment Research, 2009; William Lazonick, "The Financialization of the U.S. Corporation: What Has Been Lost, and How It Can Be Regained," Seattle University Law Review, 36, 2013: 857-909;

2 William Lazonick, "Innovative Business Models and Varieties of Capitalism: Financialization of the U.S. Corporation," Business History Review, 84, 4, 2010: 675-702.

${ }^{3}$ Lazonick, Sustainable Prosperity, chs. 2-4,

4 Ibid., ch. 5.
} 
terminated experienced workers, and offshored production to low-wage areas of the world simply to increase profits, often at the expense of the companies' long-term competitive capabilities and without regard for displaced employees' long years of service. As this new approach to corporate resource allocation became embedded in the new structure of U.S. employment, business corporations failed to invest in new, higher-value-added capabilities on a sufficient scale to create middle-class employment opportunities that could provide a new foundation for equitable and stable growth in the U.S. economy.

On the contrary, from the mid-1980s, with superior corporate performance defined as meeting Wall Street's expectations for ever-higher quarterly earnings per share, companies turned to massive stock repurchases to "manage" their own corporations' stock prices. Trillions of dollars that could have been spent on innovation and job creation in the U.S. economy over the past three decades have instead been used to buy back stock for the purpose of manipulating stock prices. Legitimizing this financialized mode of corporate resource allocation has been the ideology, itself a product of the 1980s and 1990s, that a business corporation should be run to "maximize shareholder value." 5 Through their stock-based compensation in the forms of stock options and stock awards, corporate executives who make these decisions are themselves prime beneficiaries of this focus on rising stock prices as the sole measure of corporate performance.

As a result of these three major transformations in employment relations, the paucity of wellpaid and stable employment opportunities in the U.S. economy is largely structural. But the structural problem is not, as some economists have argued, a labor-market mismatch between the skills that prospective employers want and the skills that potential workers have. ${ }^{6}$ If major employers need and want a match, they can train, and then through pay incentives retain, employees. That, in fact, was the primary reason why U.S. business corporations adopted the norm of a career with one company under the Old Economy model and why from the 1940s through most of the 1970s the real incomes of corporate employees, both blue collar and white collar, kept pace with productivity growth. For innovative companies, the match between what employers demand and what employees can supply is made in the workplace, not on the labor market.

Nor is the problem automation, a common refrain of economists who view "skill-biased technical change" (SBTC) as the most plausible explanation for the disappearance of good jobs for members of the U.S. labor force who only have a high-school education. ${ }^{7}$ As I shall elaborate in the conclusion to this essay, SBTC focuses on labor-market supply and demand to determine employment outcomes. But, especially where the adoption of new technologies is involved, employment outcomes in terms of pay and promotion are determined within the employing

\footnotetext{
5 William Lazonick and Mary O'Sullivan, "Maximizing Shareholder Value: A New Ideology for Corporate Governance," Economy and Society, 29, 1, 2000: 13-35; William Lazonick, "Innovative Enterprise and Shareholder Value," Law and Financial Markets Review, 8, 1, 2014: 52-64.

6 See, e.g., Narayana Kocherlakota, "Back Inside the FOMC," President's speeches, Federal Reserve Bank of Minnesota, 2010; Marcello Estevão and Evridiki Tsounta, "Has the Great Recession Raised U.S. Structural Unemployment?" IMF Working Paper No. 11/105, 2011 at http://www.imf.org/external/pubs/ft/wp/2011/wp11105.pdf.

7 Daron Acemoglu, "Technical Change, Inequality, and the Labor Market," Journal of Economic Literature, 40, 1, 2002: 7-72: David H. Autor, Lawrence F. Katz, and Melissa S. Kearney, "The Polarization of the U.S. Labor Market," American Economic Review, 96, 2, 2006: 189-194; Claudia Goldin and Lawrence Katz, The Race between Education and Technology, Harvard University Press, 2010; Erik Brynjolfsson and Andrew McAfee, The Second Machine Age: Work, Progress, and Prosperity in a Time of Brilliant Technologies, W. W. Norton, 2014.
} 
organizations, not in labor markets. In the United States the roots of the employment problem are systemic changes in employment relations related to rationalization, marketization, and globalization. The concomitant "financialization" of the resource-allocation decisions of U.S. business corporations has deepened the job-destroying impacts of rationalization, marketization, and globalization.

Given the dramatic changes in technology, markets, and competitors that have occurred in the world economy since the 1970 s, it would be foolish to think that the types of employment relations that most members of the U.S. labor force (especially white males) experienced in the three decades or so after World War II could have been sustained without substantial changes in conditions of work and pay. Nevertheless, the disappearance of previously existing middle-class jobs does not explain why, in a world of technological change, U.S. business corporations have failed to use their substantial profits to invest in new rounds of innovation that can create the quantity of new high-value-added jobs that a prosperous economy requires. As even the proponents of SBTC recognize, technological change can create high-skill jobs even as it may be eliminating low-skill jobs. ${ }^{8}$

The fundamental problem is the obsessive focus of the top executives of U.S. corporations on their companies' stock prices. While the old structures of stable and remunerative employment were being undermined by rationalization, marketization, and globalization, U.S. business corporations became afflicted with a socioeconomic disease known as "financialization." The prime manifestations of financialization have been, and remain, the distribution of corporate cash to shareholders through stock repurchases, often in addition to generous cash dividends, and, incentivizing these distributions, the stock-based explosion of the remuneration of top corporate executives.

In Section 2, I review evidence on the fundamental structural changes related to rationalization, marketization, and globalization that, since the early 1980s, have eroded U.S. middle-class employment opportunities. Then, in Section 3, I analyze the emergence of stock buybacks as a massive and systemic way in which corporate executives seek to boost their companies' stock prices. In this section, I identify how, in many different ways and in many different industries, this financialized mode of corporate resource allocation has undermined the prosperity of the U.S. economy. Then in Section 4, I show how this financialized behavior, justified by the ideology that companies should be run to "maximize shareholder value," boosts the remuneration of top corporate executives, providing a major explanation for the increasing concentration of income among the top $0.1 \%$ of U.S. households.

Finally, in Section 5, summing up the evidence and arguments presented in this paper, I focus on the ill-conceived SBTC approach to understanding the creation and destruction of employment opportunities in the U.S. economy. I also argue that Thomas Piketty, who has done a great service in documenting the concentration of income at the top, misnamed his best-selling book, Capital in the Twenty-First Century. ${ }^{9}$ By Piketty's own analysis of the sources of the incomes of the top $0.1 \%$ in the United States over the past three decades, his book should have been called

\footnotetext{
8 Frank Levy and Richard Murnane, The New Division of Labor: How Computers are Creating the Next Job Market, Princeton University Press, 2004.

9 Thomas Piketty, Capital in the Twenty-First Century, Harvard University Press, 2014.
} 
Labor in the Twenty-First Century. The analysis of the relation between the disappearance of middle-class jobs and the concentration of income at the top that I present in this paper should make clear why I have chosen to give this essay that title.

\section{The Disappearance of Middle-Class Jobs}

\section{a) Rationalization}

During the post-World War II decades, for both blue-collar and white-collar workers, the norm in large, established U.S. business corporations was career employment with one company. ${ }^{10}$ When layoffs occurred, they tended to be temporary and, in unionized workplaces, on a lasthired, first-fired basis. Supported by a highly progressive income tax system, countercyclical government fiscal policy sought to reduce the severity of business fluctuations, while employment generated by ongoing government spending, particularly on higher education, healthcare, advanced technology, and physical infrastructure (for example, the interstate highway system), complemented the employment opportunities provided by the business sector. The result from the late 1940s to the beginning of the 1970s was relatively equitable and stable economic growth, especially for households headed by white males.

From the late 1970s, however, in industries that had been central to U.S. innovation, employment, and growth, U.S. corporations faced formidable Japanese competition. ${ }^{11}$ The Japanese challenge came in industries such as automobiles, consumer electronics, machine tools, steel, and microelectronics in which the United States was a world leader. The critical source of Japan's competitive advantage over the United States was "organizational integration": through the hierarchical integration of shop-floor workers and the functional integration of technical specialists into processes of organizational learning, the Japanese perfected, and outcompeted, the U.S. "Old Economy" business model. ${ }^{12}$

As I have shown in my book Sustainable Prosperity in the New Economy?, the Old Economy business model had provided a large measure of stable and equitable growth to both blue-collar and white-collar male workers in the United States in the post-World War II decades. Yet, even though unionized blue-collar workers had a high degree of job security in this era, they had historically been excluded from the processes of organizational learning within the corporation, reflecting a uniquely American hierarchical segmentation between "management" and "labor."13 Faced by Japanese competition, this exclusion of shop-floor workers from the processes of organizational learning proved to be the Achilles heel of U.S. manufacturing.

An institutional pillar of Japan's economic development in the last half of the twentieth century was permanent salaried employment for male workers at both the blue-collar and white-collar levels. ${ }^{14}$ The prime source of Japanese competitive advantage was the extension of organizational

\footnotetext{
${ }^{10}$ Lazonick Sustainable Prosperity, chs. 1-4.

${ }^{11}$ Lazonick, "Innovative Business Models."

${ }^{12}$ William Lazonick, "Organizational Learning and International Competition,” in Jonathan Michie and John Grieve Smith, eds., Globalization, Growth, and Governance, Oxford University Press, 1998: 204-238

${ }^{13}$ See William Lazonick, Competitive Advantage on the Shop Floor, Harvard University Press, 1990.

${ }^{14}$ William Lazonick, "The Institutional Triad and Japanese Development" [translated into Japanese] in Glenn Hook and Akira Kudo, eds., The Contemporary Japanese Enterprise, Yukikaku Publishing, 2005, Volume 1: 55-82.
} 
learning - which is the essence of innovative enterprise - from the managerial structure populated by college-educated professional, technical, and administrative employees to shopfloor production workers, almost all with high-school educations, so that both groups working together could contribute to productivity improvements. Complementing this hierarchical integration of the learning of white-collar and blue-collar workers was the collaboration of Japanese technical specialists in solving productivity problems in manufacturing. The functional integration of their skills and efforts contrasted with the relatively high degree of functional segmentation of technical specialists in the United States. ${ }^{15}$ In sum, it was a more hierarchically and functionally integrated system of organizational learning that from the 1970s enabled Japanese manufacturers to outcompete U.S. manufacturers in a range of industries in which U.S. companies had previously been world leaders.

The particular impacts of Japanese competition varied markedly across U.S. industries. It virtually wiped out the U.S.-based consumer-electronics industry. For example, in 1981 RCA, with 119,000 employees, was one of the leading consumer-electronics companies in the world and the $44^{\text {th }}$ largest U.S. industrial company by revenues. ${ }^{16}$ By 1986 General Electric had taken over RCA and had sold it off in pieces. During the 1980s U.S. automobile manufacturers attempted to learn from the Japanese, but three decades later the U.S. companies were still producing lower-quality, higher-cost cars and, not surprisingly, had lost significant market share. ${ }^{17}$ In the machine-tool industry, the overwhelming success of the Japanese against the major U.S. companies was followed in the 1990s by the emergence of export-oriented, smalland medium-sized enterprises producing for specialized niche markets. ${ }^{18}$ In the steel industry, the innovative response of the United States was the emergence of minimills, using electric arc furnaces and scrap metal, as distinct from the traditional vertically integrated mills that converted iron ore into crude steel before making finished products. In the $1980 \mathrm{~s}$, the minimills only had the technological capability to manufacture long products such as bars and rails, but, led by Nucor, the introduction of compact strip-production technology in 1989 enabled the minimills to compete with integrated mills in flat products such as plates and sheets as well. ${ }^{19}$

The most perilous, but ultimately successful, U.S. response to Japanese competition was in the semiconductor industry. By the middle of the 1980s, the Japanese had used their integrated skill bases to lower defects and raise yields in the production of memory integrated circuits, transforming one of the most revolutionary technologies in history into mass-produced goods known as "commodity chips." This development forced major U.S. semiconductor companies to retreat from the memory segment of the market, with Intel, a key U.S. chip company, facing the

\footnotetext{
${ }^{15}$ Kim B. Clark and Takahiro Fujimoto, Product Development Performance: Strategy, Organization, and Management in the World Auto Industry, Harvard Business School Press, 1991; Lazonick, "Organizational Learning”; Lazonick, "Innovative Business Models."

${ }^{16}$ Alfred D. Chandler, Jr., Inventing the Electronic Century: The Epic Story of the Consumer Electronics and Computer Industries, Free Press, pp. 13-49.

${ }^{17}$ Michaela D. Platzer and Glennon J. Harrison, “The U.S. Automotive Industry: National and State Trends in Manufacturing Employment," Congressional Research Service, R40746, 2009, at http://digitalcommons.ilr.cornell.edu/key_workplace/666.

${ }^{18}$ Ronald V. Kalafsky and Alan D. MacPherson, "The Competitive Characteristics of U.S. Manufacturers in the Machine Tool Industry," Small Business Economics, 19, 4, 2002: 354-369.

${ }^{19}$ Frank Giarratani, Gene Gruver, and Randall Jackson, "Clusters, Agglomeration, and Economic Development Potential: Empirical Evidence Based on the Advent of Slab Casting by U.S. Steel Minimills," Economic Development Quarterly, 21, 2, 2007: $148-164$.
} 
possibility of bankruptcy in the process. ${ }^{20}$ Since 1981 , however, Intel had been producing microprocessors for the IBM PC and its clones, and on this basis emerged by the beginning of the 1990s as the world's leading chip manufacturer. More generally, during the 1980s, as the Japanese (and then the South Koreans) were taking over the memory-chip market, U.S. companies became world leaders in the production of logic integrated circuits, where value was added through chip design rather than manufacturing yield, the area in which the Japanese now excelled. Indeed, relying on the Intel microprocessor and the Microsoft operating system, the rapid emergence of the IBM PC as the industry "open systems" - or "Wintel" - standard in the years after its launch in 1981 was the basis for the rise of a "New Economy business model" with rationalization, marketization, and globalization of employment relations in its DNA. ${ }^{21}$

The adverse impact on U.S. employment of Japanese competition in consumer electronics, automobiles, steel, and machine tools became particularly harsh in the double-dip recession of 1980-1982 when large numbers of blue-collar jobs permanently disappeared from U.S. industry. ${ }^{22}$ Previously, in a more stable competitive environment, U.S. manufacturing companies would lay off workers with the least seniority in a downturn and re-employ them when economic conditions improved. In the 1980s, however, it became commonplace for companies to shutter whole plants. ${ }^{23}$ From 1980 to 1985 , employment in the U.S. economy increased from 104.5 million to 107.2 million workers, or by $2.6 \%$. But employment of operators, fabricators, and laborers fell from 20 million to 16.8 million, a decline of $15.9 \% .^{24}$

As Daniel Hamermesh observed, "each year during the eighties, plant closings in the U.S. displaced roughly one-half million workers with three-plus years on the job." 25 Over the course of the 1980s, the stock market came to react favorably to permanent downsizings of the bluecollar labor force. ${ }^{26} \mathrm{As}$ secure middle-class jobs for high-school-educated blue-collar workers permanently disappeared, there was no commitment on the part of those who managed U.S. industrial corporations, or the Republican administrations that ruled in the 1980s, to invest in the new capabilities and opportunities required to upgrade the quality, and expand the quantity, of well-paid employment opportunities in the United States on a scale sufficient to reestablish conditions of prosperity for these displaced members of the labor force.

${ }^{20}$ Robert A. Burgelman, "Fading Memories: A Process Theory of Strategic Business Exit in Dynamic Environments," Administrative Science Quarterly, 39, 1, 1994: 24-56; Daniel I. Okimoto and Yoshio Nishi. "R\&D Organization in Japanese and American Semiconductor Firms," in Masahiko Aoki and Ronald Dore, eds., The Japanese Firm: The Sources of Competitive Strength, Oxford University Press, 1994: 178-208.

${ }^{21}$ Lazonick, Sustainable Prosperity.

${ }^{22}$ Robert W. Bednarzik, "Layoffs and Permanent Job Losses: Workers' Traits and Cyclical Patterns," Monthly Labor Review, September, 1983: 3-12.

${ }^{23}$ Daniel S. Hamermesh, "What Do We Know About Worker Displacement in the U.S.?” Industrial Relations, 28, 1, 1989: 5159; Candee S. Harris, "The Magnitude of Job Loss from Plant Closings and the Generation of Replacement Jobs: Some Recent Evidence," Annals of the American Academy of Political and Social Science, 475, 1984: 15-27.

${ }^{24}$ U.S. Department of Commerce, Bureau of the Census, Statistical Abstract of the United States 1984, 104 ${ }^{\text {th }}$ edition, U.S. Government Printing Office, 1983, p. 416; U.S. Department of Commerce, Bureau of the Census, Statistical Abstract of the United States 1987, $107^{\text {th }}$ edition, U.S. Government Printing Office, 1986, p. 386.

${ }^{25}$ Hamermesh, "What Do We Know," p. 53.

${ }^{26}$ John M. Abowd, George T. Milkovich, and John M. Hannon, "The Effects of Human Resource Management Decisions on Shareholder Value," Industrial and Labor Relations Review, 43, Special Issue: 1990: 203S-233S; Oded Palmon, Huey-Lian Sun, and Alex P. Tang, "Layoff Announcements: Stock Market Impact and Financial Performance," Financial Management, 26, 3, 1997: 54-68. 
Among blue-collar workers, blacks were extremely hard hit by the rationalization of employment in the 1980s. They were overrepresented in the mass-production sectors of the Old Economy, such as steel, autos, and consumer electronics, and underrepresented in the rising sectors of the New Economy related to the microelectronics revolution. Besides losing jobs when plants were closed, many blacks had recently moved into unionized jobs, so that when some workers in an establishment were laid off, blacks were more likely to have been the last hired and hence were the first fired.$^{27}$ The disappearance of these middle-class jobs had devastating impacts on the abilities and incentives of blacks to accumulate the education and experience required to position themselves for the types of well-paid and stable employment opportunities that remained. ${ }^{28}$

In historical retrospect, we now know that the recoveries that followed the recessions of 19901991, 2001, and 2007-2009 were "jobless": macroeconomic growth was not accompanied by job growth. Technically, the recovery from the recessionary conditions of 1980-1982 was not "jobless" because employment opportunities created by the microelectronics boom in the first half of the 1980s offset the joblessness that remained in the traditional manufacturing sector as the U.S. economy began to grow. For example, from 1980 to 1985, employment of mathematical and computer engineers increased from 330,000 to 571,000 , or by $73 \%$, and employment of computer programmers increased from 318,000 to 534,000 , or by $68 \% .^{29}$ In the expansion of 1983-1985, however, workers in traditional manufacturing industries, who typically held only high-school diplomas, experienced the first of four jobless recoveries of the last three decades.

\section{b) Marketization}

As for the New Economy, the recovery from the recession of 1980-1982 saw the emergence of the Wintel architecture around the IBM PC. ${ }^{30}$ In 1982 IBM's PC sales were $\$ 500$ million. Just two years later, sales had soared to eleven times that amount - more than triple the 1984 revenues of Apple, its nearest competitor, and about equal to the revenues of IBM's top eight rivals. Subsequently, the very success of the IBM PC, combined with open access to the Microsoft operating system and the Intel microprocessor, meant that in the last half of the 1980s and beyond IBM lost market share to lower priced PC clones produced by New Economy companies such as Compaq, Gateway, and Dell. ${ }^{31}$ Competition based on open systems had become the norm. ${ }^{32}$

With the microelectronics revolution of the 1980s, New Economy companies in the information and communication technology (ICT) industries found themselves in competition for professional, technical, and administrative labor with Old Economy ICT companies such as Hewlett-Packard, IBM, Motorola, Texas Instruments, and Xerox that in the 1980s still offered

\footnotetext{
${ }^{27}$ Lori Kletzer, "Job Displacement," Journal of Economic Perspectives, 12, 1, 1998: 115-136; Ronald Fairlie and Lori Kletzer, "Jobs Lost, Jobs Regained: An Analysis of Black/White Differences in Job Displacement in the 1980s," Industrial Relations, 37, 4, 1998: 460-477; Rochelle Sharpe, "Unequal opportunity: Losing ground on the employment front," Wall Street Journal, September 14, 1993.

${ }^{28}$ William Julius Wilson, "When Work Disappears," Political Science Quarterly, 111, 4, 1996-97: 567-595.

${ }^{29}$ U.S. Department of Commerce, Statistical Abstract 1984, p. 416; Statistical Abstract 1987, p. 386.

${ }^{30}$ Michael Borrus and John Zysman, "Wintelism and the Changing Terms of Global Competition: Prototype of the Future?” BRIE Working Paper No. 96B, University of California, Berkeley, 1997.

${ }^{31}$ Chandler, Inventing the Electronic Century, pp. 118-119, 142-143.

${ }^{32}$ Henry Chesbrough, Open Innovation: The New Imperative for Creating and Profiting from Technology, Harvard Business School Press, 2006.
} 
employees the realistic prospect of a career with one company. ${ }^{33}$ As young firms facing a highly uncertain future, New Economy companies could not attract labor away from Old Economy companies by promises of career employment. Instead, the New Economy startups used the inducement of employee stock options to attract and retain employees - very high proportions of whom were college educated. As the successful New Economy companies grew large, most, if not all, employees were partially compensated in stock options. For example, Cisco Systems had 250 employees in 1990, the year in which it became publicly traded. After it had come to dominate the Internet router market a decade later, it had over 34,000 employees, virtually all of whom received stock options as part of their compensation. ${ }^{34}$

So that stock options would perform a retention function as well as an attraction function, the practice evolved in New Economy firms of making option grants annually, with $25 \%$ of an annual block of option grants vesting at the end of each of the first four years after the grant date. Once the options are vested, they can typically be exercised for a period of ten years from the grant date, so long as the employee remains with the company. Without creating the Old Economy expectation among employees of lifelong careers with the company, the perpetual pipeline of unvested options functions as a tangible retention mechanism. Indeed, for most employees, the amount of options that an individual can expect to receive is tied to his or her position in the firm's hierarchical and functional division of labor, so that the retention function of stock options is integrally related to the employee's career progress within the particular company. ${ }^{35}$

Nevertheless, it is important to recognize that the original labor-market function of broad-based employee stock-option programs from the early 1980s was to induce high-tech personnel to leave secure employment in established Old Economy corporations to take up insecure employment in New Economy startups. When New Economy companies such as Dell, Microsoft, and Cisco grew to be large, the Old Economy norm of a career with one company did not reappear. Rather during the 1990s the norm of a career with one company disappeared at Old Economy corporations as well. ${ }^{36}$

Old Economy companies such as IBM, Hewlett-Packard, and Motorola had valued career employees because of their organizational experience in developing and utilizing the company's proprietary technologies. At many of the leading companies, the corporate research lab was the main source of this intellectual property. Investment in new products and processes was often done on military contracts, with the adaptation of the technologies to commercial production as process technologies improved and unit costs fell through achieving economies of scale. Old Economy companies passed on some of their productivity gains to their employees in the forms of higher wages and employment security, thus underpinning higher standards of living in the economy as a whole. In short, the Old Economy norm of a career with one company provided

\footnotetext{
${ }^{33}$ Lazonick, Sustainable Prosperity, pp. 81-113.

${ }^{34}$ Ibid., pp. 39-79.

${ }^{35}$ Ibid., pp. 39-79, 115-147.

${ }^{36}$ Ibid., ch. 3 .
} 
the foundation for relatively stable and equitable economic growth in the post-World War II decades. $^{37}$

The recession and recovery of the early 1990s witnessed the marketization of the employment relation and marked the beginning of the end of the career-with-one-company norm, as, in effect, long-established companies made the transition from the Old Economy business model to the New Economy business model. Although in absolute terms, blue-collar workers suffered more unemployment than white-collar workers during the recession of the early 1990s, the extent to which professional, technical, and administrative employees were terminated was unprecedented in the post-World War II decades. Hence the downturn of 1990-1991 became known as the "white collar recession." ${ }^{38}$ Increasingly over the course of the 1990s, including during the Internet boom in the second half of the decade, the career-long employment security that people in their forties and fifties had come to expect under the Old Economy business model vanished as employers replaced more-expensive older workers with less-expensive younger workers. ${ }^{39}$

Given its size, reputation, and central position in ICT industries, the dramatic changes at IBM in the early 1990s marked a fundamental juncture in the transition from employment security to employment insecurity in the U.S. corporate economy. Through the 1980s IBM touted its practice of "lifelong employment" as a source of its competitive success. ${ }^{40}$ From 1990 to 1994 , however, IBM cut employment from 373,816 to 219,839 ; this net reduction of 154,000 jobs dropped its labor force to only $59 \%$ of its year-end 1990 level. ${ }^{41}$ During this period, much of IBM's downsizing was accomplished by making it attractive for its employees to accept voluntary severance packages, including early retirement at age fifty-five. But in 1993 and 1994, after recruiting CEO Louis V. Gerstner, Jr. from RJR Nabisco, many thousands of IBM employees were fired outright. In 1995, IBM rescinded the early-retirement offer that had helped downsize its labor force. The offer had accomplished its purpose, and in any case IBM no longer wanted to encourage all employees to remain with the company even until the age of fifty-five.

Of IBM's losses of $\$ 15.9$ billion in 1991-1993 (including an $\$ 8.1$ billion deficit in 1993, the largest annual loss in U.S. corporate history to that time), $86 \%$ came from workforce-related restructuring charges, including the cost of employee separations and relocations. This loss was, in effect, the cost to the company of ridding itself of its once-hallowed tradition of lifelong employment. Ignoring restructuring charges, IBM recorded positive net incomes before taxes of $\$ 939$ million in 1991, \$2.619 billion in 1992, and \$148 million in 1993. Although IBM continued to downsize at a torrid pace in 1994, most of the downsizing was done outside the United States and without voluntary severance provisions. During 1994, the company booked no restructuring charges and had after-tax profits of $\$ 3.021$ billion. By that time, lifelong employment at IBM was a thing of the past.

\footnotetext{
${ }^{37}$ Ibid., pp. 81-113; William Lazonick, “Alfred Chandler's Managerial Revolution: Developing and Utilizing Productive Resources," in William Lazonick and David J. Teece, eds., Management Innovation: Essays in the Spirit of Alfred D. Chandler, Jr., Oxford University Press, 2012: 3-29.

${ }^{38}$ Randall W. Eberts and Erica L Groshen, "Is This Really a 'White-Collar Recession'?” Economic Commentary, Federal Reserve Bank of Cleveland, 1991; Jennifer M. Gardner, “The 1990-91 Recession: How Bad Was the Labor Market?” Monthly Labor Review, June 1994: 3-11.

${ }^{39}$ Lazonick, Sustainable Prosperity, pp. 81-113, 249-279

${ }^{40}$ Joel Kotkin, "Is IBM good for America?" Washington Post, October 6, 1985; Thomas J. Watson, Jr. and Peter Petrie, Father, Son, and Company: My Life at IBM and Beyond, Bantam, 1990, pp. 288-289.

${ }^{41}$ The following account is based on Lazonick, Sustainable Prosperity, pp. 85-89.
} 
In line with the IBM transition, John Abowd and his co-authors found a general shift in U.S. employment from older experienced workers to younger skilled workers from 1992 to 1997 as companies adopted computer technologies. ${ }^{42}$ Using Current Population Survey data, Charles Schultze discovered that "[m]iddle-aged and older men, for whatever reason, are not staying as long with their employers as they once did. ${ }^{43} \mathrm{He}$ went on to show, moreover, that the job displacement rate for white-collar workers relative to blue-collar workers had risen substantially over the course of the 1980s and 1990s, starting at 33\% in 1981-1982 and increasing to about $80 \%$ in the 1990s. Lori Kletzer wrote in a 1998 survey article on "job displacement":

Job loss rates fell steadily from the 1981-83 rate, which encompassed the recession of 1981-82, through the expansion period of 1983-89. Job loss rates then rose again in 1989-91 as the economy weakened. The latest job loss figures are surprising. In the midst of a sustained (if uneven) expansion, 1993-95 job loss rates are the highest of the 14-year period: about 15 percent of U.S. workers were displaced from a job at some time during this three-year period. These high rates of job loss are consistent with public perceptions of rising job insecurity. ${ }^{44}$,

In a survey of changes in job security from the 1970s to the 2000s, Henry Farber stated that "there is ample evidence that long-term employment [with one company] is on the decline in the United States." 45 Using Current Population Survey data, Farber found that mean tenure for males employed in the private sector has declined substantially, particularly for older workers. For example, mean tenure for private sector males at age fifty declined from 13.5 years in the 1973 to 1983 period to 11.3 years in the 1996 to 2008 period. The pattern in the public sector is the opposite. For example, mean tenure for public sector males at age fifty increased from 13.6 years in the 1973 to 1983 period to 15.8 years in the 1996 to 2008 period. ${ }^{46}$

Moreover, it appears that education as a guarantor of employment security weakened significantly from the 1980 s to the 2000s. Using Displaced Worker Survey data to analyze rates of job loss, Farber found that

in 1981 to 1983 , the private-sector three-year job loss rate was 16 percent for high school graduates and 9.4 percent for college graduates. By 2001 to 2003 (also a period of weak labor markets), the gap had fallen to virtually zero, with a private-sector three-year job loss rate of 10.7 percent for high school graduates and 11 percent for college graduates. Interestingly, the education gap in job loss rates increased in the 2005 to 2007 period with 8.3 and 10.0 percent job loss rates for high school and college graduates, respectively. ${ }^{47}$

\footnotetext{
42 John Abowd, John Haltiwanger, Julia Lane, Kevin L. McKinney, and Kristin Sandusky, "Technology and the Demand for Skill: An Analysis of Within and Between Firm Differences," NBER Working Paper No.13043, National Bureau of Economic Research, 2007.

${ }^{43}$ Charles L. Schultze, "Downsized \& Out: Job Security and American Workers," Brookings Review, 17, 4, 1999: 9-17.

${ }^{44}$ Kletzer, "Job Displacement."

${ }^{45}$ Henry Farber, "Job Loss and the Decline of Job Security in the United States," in Katharine G. Abraham, James R. Spletzer, and Michael Harper, eds., Labor in the New Economy, University of Chicago Press, 2010: 223-262.

${ }^{46}$ Ibid., p. 230.

${ }^{47}$ Ibid., p. 253.
} 


\section{c) Globalization}

In the 2000s, globalization joined rationalization and marketization as a source of structural change in U.S. employment relations. In the ICT industries that were central to the growth of the U.S. economy in the 1980s and 1990s, the globalization of employment dated back to the 1960s, when U.S. semiconductor manufacturers had set up assembly and testing facilities in East Asia, making use of low-paid but literate female labor. ${ }^{48}$ Over time, a combination of work experience with multinational and indigenous companies, as well as the return of nationals who had acquired graduate education and work experience abroad, enhanced the capability of the Asian labor force to engage in higher value-added activities.

By the beginning of the 2000s, Indians had become world leaders in the offshore provision of IT services, while the Chinese had become adept in a wide range of manufacturing industries, especially in ICT. China and India inserted themselves into the global value chains that became an organizational characteristic of the New Economy business model. In the 2000s, the availability of capable, college-educated labor supplies in developing economies along with high-quality, low-cost communication networks enabled a vast acceleration of the movement of jobs by U.S. companies to China and India. ${ }^{49}$ In both countries, indigenous and foreign-owned high-tech companies were by the 2000s well positioned to move rapidly up the global value chains.

Offshoring depressed U.S. employment in the recession of 2001 and in the subsequent jobless recovery that stretched into 2003. As U.S.-based companies hired workers abroad, well-educated high-tech workers in the United States found themselves vulnerable to displacement. ${ }^{50}$ Given huge increases in the issuance of nonimmigrant (H-1B and L-1) work visas in the United States in the late 1990s and early 2000s, there were hundreds of thousands of high-tech workers, especially Indians, who had accumulated U.S. work experience that they could now take back home. ${ }^{51}$ In February 2003, after more than a year of jobless recovery, BusinessWeek gained considerable attention when its cover blared the rhetorical question: "Is Your Job Next?"52 The subtitle read: "A new round of globalization is sending upscale jobs offshore. They include chip design, engineering, basic research - even financial analysis. Can America lose these jobs and still prosper?"

\footnotetext{
${ }^{48}$ Lazonick, Sustainable Prosperity, ch. 5

${ }^{49}$ Kate Bronfenbrenner and Stephanie Luce, "The Changing Nature of Global Corporate Restructuring: The Impact of Production Shifts on Jobs in the US, China, and Around the Globe," submitted to the US-China Economic and Security Review Commission, October 14, 2004 at http://www.goiam.org/publications/pdfs/cornell_u_mass_report.pdf; Robert W. Bednarzik, "Restructuring Information Technology: Is Offshoring a Concern?" Monthly Labor Review, August 2005: 11-20; Alan S. Blinder, "How Many U.S. Jobs May be Offshorable?" CEPS Working Paper No. 142, Princeton University, March, 2007; Rona Hira and Anil Hira, Outsourcing America: The True Cost of Shipping Jobs Overseas and What Can Be Done About It, revised edition, AMACOM, 2008; Susan N. Houseman, "Measuring Offshore Outsourcing and Offshoring: Problems for Economic Statistics," Employment Research, 16, 1, 2009: 1-3; Susan N. Houseman, "The Role of Manufacturing in a Jobs Recovery," Center on Budget and Policy Priorities, April 2, 2014, at http:/www.pathtofullemployment.org/wpcontent/uploads/2014/04/houseman.pdf.

${ }^{50}$ C. Alan Garner, "Offshoring in the Service Sector: Economic Impact and Policy Issues," Economic Review, Federal Reserve Bank of Kansas City, Third Quarter, 2004: 5-37; J. Bradford Jensen and Lori B. Kletzer, "Tradable Services: Understanding the Scope and Impact of Services Outsourcing," Institute for International Economics Working Paper 05-9, September, 2005.

${ }^{51}$ Ron Hira, "Bridge to Immigration or Cheap Temporary Labor? The H-1B \& L-1 Visa Programs Are a Source of Both," Economic Policy Institute Briefing Paper \#257, February 17. 2010.

52 Pete Engardio, Aaron Bernstein, and Manjeet Kripalani, “The great global job shift,” Business Week, February 3, 2003.
} 
For three decades now, the U.S. economy has been losing unionized blue-collar jobs. As it turns out, Democratic administrations have been no better than Republican administrations in stanching the decline. ${ }^{53}$ In 2014 the U.S. rate of business-sector unionization was $6.6 \%$, having declined steadily from more than $15 \%$ in $1983 .{ }^{54}$ Since the early 1990 s, nonunionized whitecollar workers, including professional, technical, and administrative employees who are deemed to be members of "management," have found that they can no longer expect that they will have a career with one company. The shift to open-systems technologies and the globalization of hightech jobs have rendered highly educated and highly experienced members of the U.S. labor force vulnerable to loss of career employment. Meanwhile since 1960, through a tax policy that exempts U.S. companies from paying corporate taxes on their foreign profits until those profits are repatriated to the United States, the U.S. government has given U.S. companies an incentive to make profits abroad and keep them there. The Obama administration has promised to get rid of this tax loophole, but, even before the Republicans took control of the House of Representatives in November 2010, the President caved in the presence of vociferous opposition from high-tech executives. ${ }^{55}$

It should be emphasized once again that the displacement of workers from middle-class jobs has often had a productive rationale: manufacturing plants may become uncompetitive; recently educated workers may possess more relevant skills than experienced (older) workers; and the productive capabilities of workers in low-wage areas of the world may be on a par with, if not superior to, those of workers in the United States. Nevertheless, once changes in the structure of employment have become widespread for productive reasons, corporations have been known to terminate employees in order to increase short-term profits for the sake of inciting speculative increases in their companies' stock prices. As documented below, under a regime of financialized corporate resource allocation, the tendency has then been to allocate those extra profits to stock buybacks for the purpose of giving a company's stock price a manipulative boost.

Unlike the recessions of 1980-1982, 1990-1991, and 2001, the Great Recession of 2008-2009 was a purely financial downturn caused by speculation in, and manipulation of, securities markets by the financial sector of the economy. This speculation and manipulation exploited the fragility of home ownership in an economy that, since the 1980s, had been eliminating the stable and remunerative middle-class jobs that had made home ownership affordable. The jobless recovery that has followed the Great Recession has been far more prolonged than earlier ones. While Wall Street has become, and remains, a gambling casino, the more fundamental fragility of the U.S. economy emanates from the industrial sector to which the vast majority of households look for employment that can sustain middle-class living standards. In the following sections of this essay, I shall show that, as a general rule, the executives who run U.S. industrial corporations have become focused on creating profits for the sake of higher stock prices rather than creating the high value-added jobs that are the essence of a prosperous economy.

\footnotetext{
${ }^{53}$ Louis Uchitelle, The Disposable American: Layoffs and their Consequences, Vintage, 2007.

${ }^{54}$ Bureau of Labor Statistics, “Union Members-2014," January 23, 2015, at http://www.bls.gov/news.release/union2.nr0.htm.

${ }^{55}$ William Lazonick, "The global tax dodgers: How big business keeps money overseas instead of creating jobs at home," AlterNet, August 31, 2011; Lazonick, "The Financialization of the U.S. Corporation," pp. 900-903. For the amount of cash that U.S. corporations are holding abroad, see International Strategy and Investment (ISI), "Accounting and Tax Research: Cash \& Earnings Parked Overseas," ISI report, March 17, 2014.
} 


\section{Financialization of the U.S. Business Corporation}

\section{a) Income inequality}

In the generally prosperous U.S. economy of the post-World War II decades, there was a movement toward more equality in the distribution of income, as illustrated by the time series for the Gini coefficient in Figure 1. In the late 1970s there was a reversal of this trend, followed by accelerating inequality from the early 1980s. As measured by the Gini coefficient, income inequality increased in almost all of the countries in the Organisation for Economic Co-operation and Development (OECD) from the mid-1980s to the late 2000s. The United States, however, has had the most unequal distribution in the OECD except for Turkey and Mexico. ${ }^{56}$

\section{Figure 1: Gini coefficient as an indicator of income distribution among all U.S. families, 1947-2013}

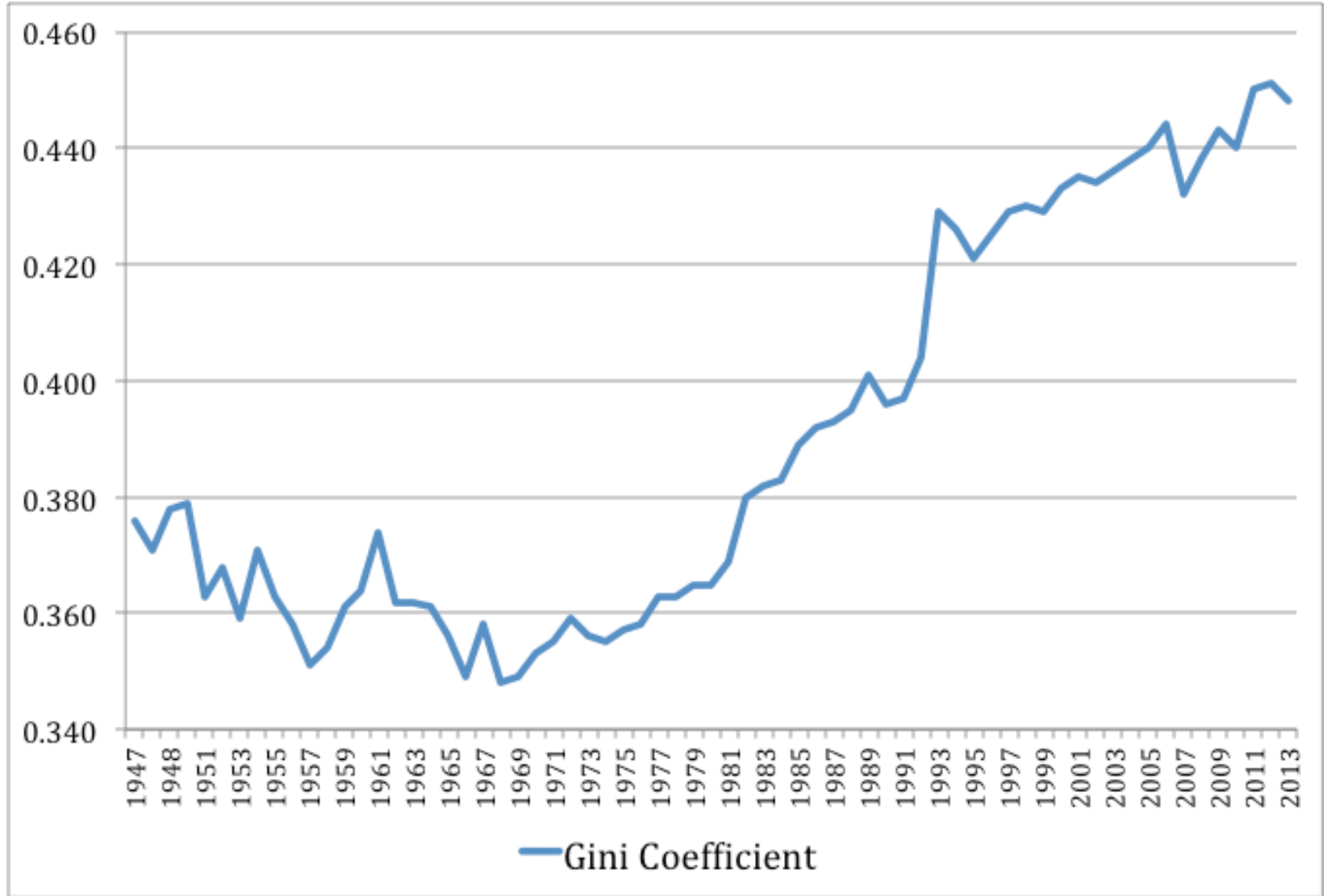

Source: U.S. Census Bureau, Historical Income Tables Families, Table F-4, at http://www.census.gov/hhes/www/income/data/historical/families/.

Note: The Gini coefficient is a widely used measure of income inequality. A Gini coefficient of 0 would mean perfect equality in the distribution of income among all families in the economy, while a coefficient of 1 would mean that one family has all the income and all of the remaining families in the economy have none. The higher the Gini coefficient, therefore, the greater the income inequality among families in the economy concerned.

\footnotetext{
${ }^{56}$ OECD, “Growing Income Inequality in OECD Countries: What Drives It and How Can Policy Tackle It?' OECD Forum on Tackling Income Inequality, Paris, May 2, 2011.
} 
In the post-World War II decades, the guiding principles of corporate resource allocation can be summed up as "retain-and-reinvest." ${ }^{57}$ Business corporations retained earnings and reinvested them in productive capabilities, including the capabilities of employees who, in helping to make the enterprise more productive and competitive, benefited in the forms of higher incomes and more employment security. Retain-and-reinvest is a resource-allocation regime that supports value creation at the business level and implements a process of value extraction through which the firm shares the productivity gains with a broad base of employees. ${ }^{58}$

Figure 2a shows that from the late 1940s to the late 1970s changes in real wages tracked changes in productivity in the U.S. economy. In my view, the retain-and-reinvest employment policies of major U.S. corporations largely accounted for this result. ${ }^{59}$ The sharing of the gains of productivity growth with white-male career employees, including among them both union bluecollar workers with high-school educations and non-union white-collar workers with college educations, underpinned the resultant trend toward greater income equality in the United States from the late 1940s well into the 1970s, as charted by the Gini coefficient in Figure 1.

Figure 2a. Cumulative annual percent changes in productivity and real wages in the United States, 1948-1983

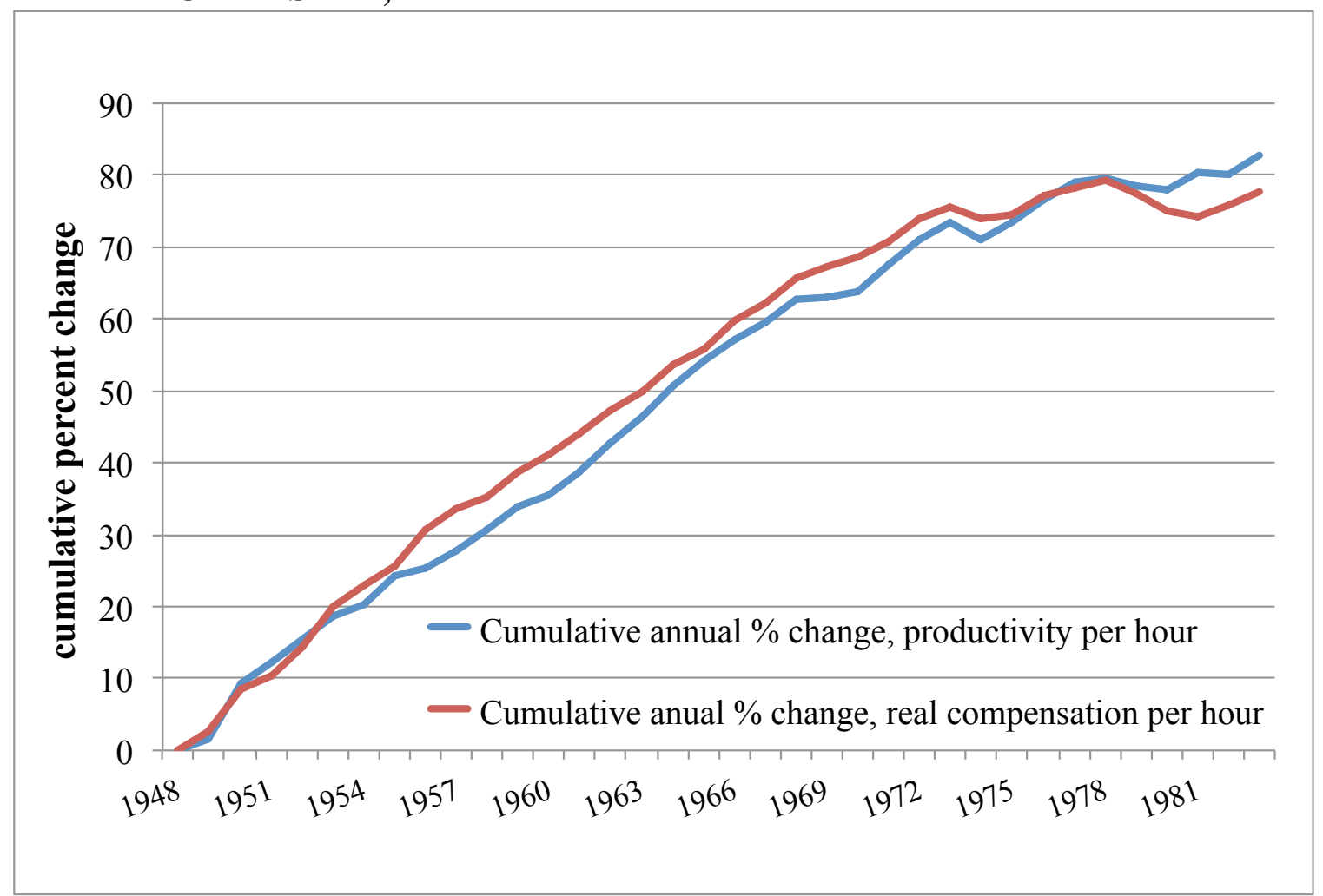

Source: http://www.econdataus.com/wagegap12.html

As shown in Figure 2b, however, since the late 1970s there has been a widening gap between the growth in productivity and the growth in real wages. This gap, I would argue, is largely the result

\footnotetext{
${ }^{57}$ Lazonick and O'Sullivan, "Maximizing Shareholder Value".

${ }^{58}$ Lazonick, Sustainable Prosperity. See also Lazonick, Competitive Advantage on the Shop Floor.

${ }^{59}$ Lazonick, Sustainable Prosperity, ch. 3.
} 
of a shift of corporate resource allocation to a "downsize-and-distribute" regime in which corporate executives look for opportunities to downsize the labor force and distribute earnings to shareholders. Had corporate executives made different allocation decisions, a portion of the earnings that were paid out to shareholders could have been invested in, among other things, the productive capabilities of the people thrown out of work. Downsize-and-distribute is a resourceallocation regime that supports value extraction at the business level that may enrich financial interests at the expense of employees who contributed to the process of value creation that generated those earnings in the first place. As a result, a downsize-and-distribute allocation regime contributes to employment instability and income inequity. ${ }^{60}$

Figure 2b. Cumulative annual percent changes in productivity and real wages in the United States, 1963-2012

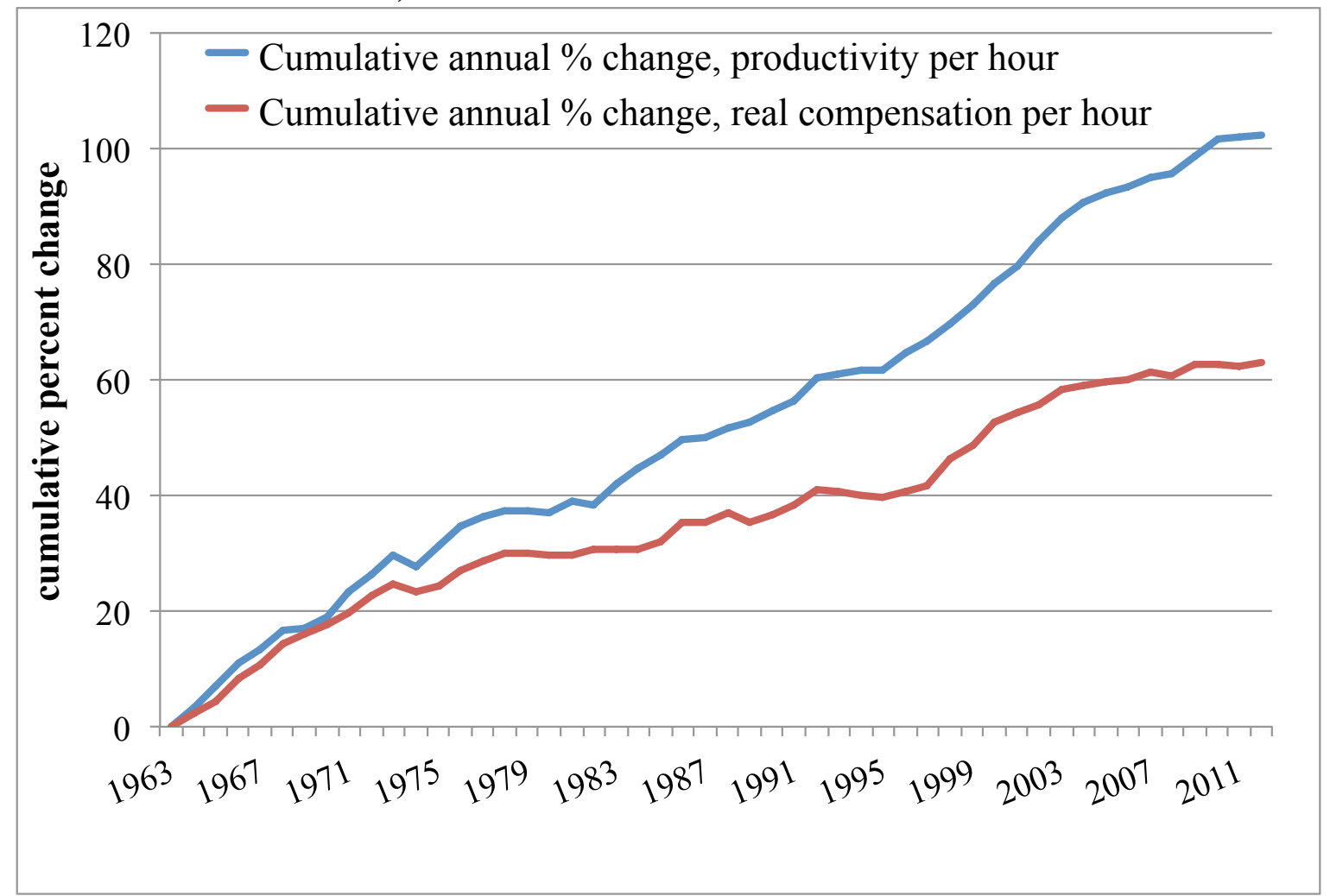

Source: http://www.econdataus.com/wagegap12.html

Downsizing of the existing U.S. labor force is inherent in rationalization, marketization and globalization. As stated earlier, initially it was possible to justify these changes in employment relations as responses to changes in technological, market, and competitive conditions that even powerful business enterprises could not ignore. The critical issue is how the business enterprise reallocates its productive resources in the face of these changing industrial conditions. Is the corporation downsizing its labor force for the sake of reallocating the company's resources to

${ }^{60}$ William Lazonick, "Creating and Extracting Value: Corporate Investment Behavior and American Economic Performance," in Michael Bernstein and David Adler, eds., Understanding American Economic Decline, Cambridge University Press, 1994: 79-113. William Lazonick, "Corporate Restructuring," in Stephen Ackroyd, Rose Batt, Paul Thompson, and Pamela Tolbert, eds., The Oxford Handbook of Work and Organization, Oxford University Press, 2004: 577-601; William Lazonick and Mariana Mazzucato, "The Risk-Reward Nexus in the Innovation-Inequality Relationship," Industrial and Corporate Change, 22, 4, 2013: 1093-1128. 
investment in new productive capabilities, or is it engaging in downsizing just to boost its shortterm profitability? And if the purpose of downsizing is the latter, what does the corporation do with the increased profits that downsizing makes possible? Do executives who make corporate decisions concerning the allocation of labor and capital use the "free cash flow" generated by downsizing to increase payouts to shareholders? And if so, why?

\section{b) Stock buybacks}

In answering these questions, it must be recognized that for a business enterprise that has made the transition from a new venture to a going concern, earnings retained out of profits provide the financial foundation for investing in the productive capabilities that it needs to generate competitive goods and services in the future. Corporate retentions can be used to invest in plant and equipment, research and development, and retraining and retaining the labor force (some but not all of which are included in R\&D expenses). The higher incomes that "retained" workers receive can serve as both incentives for these employees to continue to supply their skills and efforts to the company and rewards for their past contributions to the company's current profitability. In addition, the taxes that corporations pay out of their profits help fund government investments in physical infrastructure and human knowledge that business enterprises are unable (or unwilling) to finance themselves. ${ }^{61}$

Downsize-and-distribute occurs, therefore, when the business enterprise not only downsizes its labor force but distributes the resultant "free" cash flow to shareholders in the name of "maximizing shareholder value" (MSV). During the 1980s, the retain-and-reinvest mode of resource allocation that characterized the post-World War II decades came under attack from Reaganite deregulation, hostile takeovers, and corporate restructuring, all of which gained legitimacy from MSV ideology. ${ }^{62}$ Embracing this new agenda, by the last half of the 1980s U.S. corporate executives became focused on distributing corporate cash to shareholders through open-market stock repurchases, which had previously been an unimportant mode of payouts to shareholders. These stock buybacks have been in addition to cash dividends, the traditional way of paying out corporate cash to shareholders.

MSV portrayed "downsize-and-distribute" as a mode of resource allocation that disgorged cash from inefficient companies for the sake of reinvestment in efficient ones. In fact, the disgorged cash has supported the rise of the financial sector of the economy, with the augmented value that financial interests have been able to extract increasing the amount of "capital" chasing high yields on financial markets instead of investing in the productive capabilities that can create new sources of value. Since the 1980s stock buybacks have become integral to "downsize-anddistribute," and hence a prime reason for both the erosion of stable, remunerative employment opportunities and the extreme concentration of income among the very richest households.

Dividends provide shareholders with a yield for, as the name says, holding stock. In contrast, buybacks provide shareholders with a yield for selling stock; that is, for ceasing to be shareholders. While increasing buybacks, U.S. companies have not been stingy with their

\footnotetext{
${ }^{61}$ William Lazonick, "The Innovative Enterprise and the Developmental State: Organizational Foundations for Economic Prosperity," AIR working paper, revised version forthcoming.

${ }^{62}$ Lazonick and O’Sullivan, "Maximizing Shareholder Value."
} 
dividend payouts. Since the 1980 s, the ratio of dividends to net income for all U.S. corporations rose from $37 \%$ in both the 1960 s and 1970 s to $46 \%$ in the 1980 s to $58 \%$ in the 1990 s to $63 \%$ in the 2000s. ${ }^{63}$ Meanwhile, especially for the largest and most profitable corporations on which economic prosperity relies, stock buybacks became an even larger source of cash distributions to public shareholders.

Figure 3 shows net equity issues of U.S. corporations from 1946 to 2014. Net equity issues are new corporate stock issues minus outstanding stock retired through stock repurchases and M\&A activity. Since the mid-1980s in aggregate, corporations have funded the stock market rather than vice versa (as is conventionally assumed). ${ }^{64}$ Over the decade 2005-2014 net equity issues of nonfinancial corporations averaged minus \$399 billion per year.

Figure 3. Net equity issues, U.S. nonfinancial and financial companies, 1946-2014

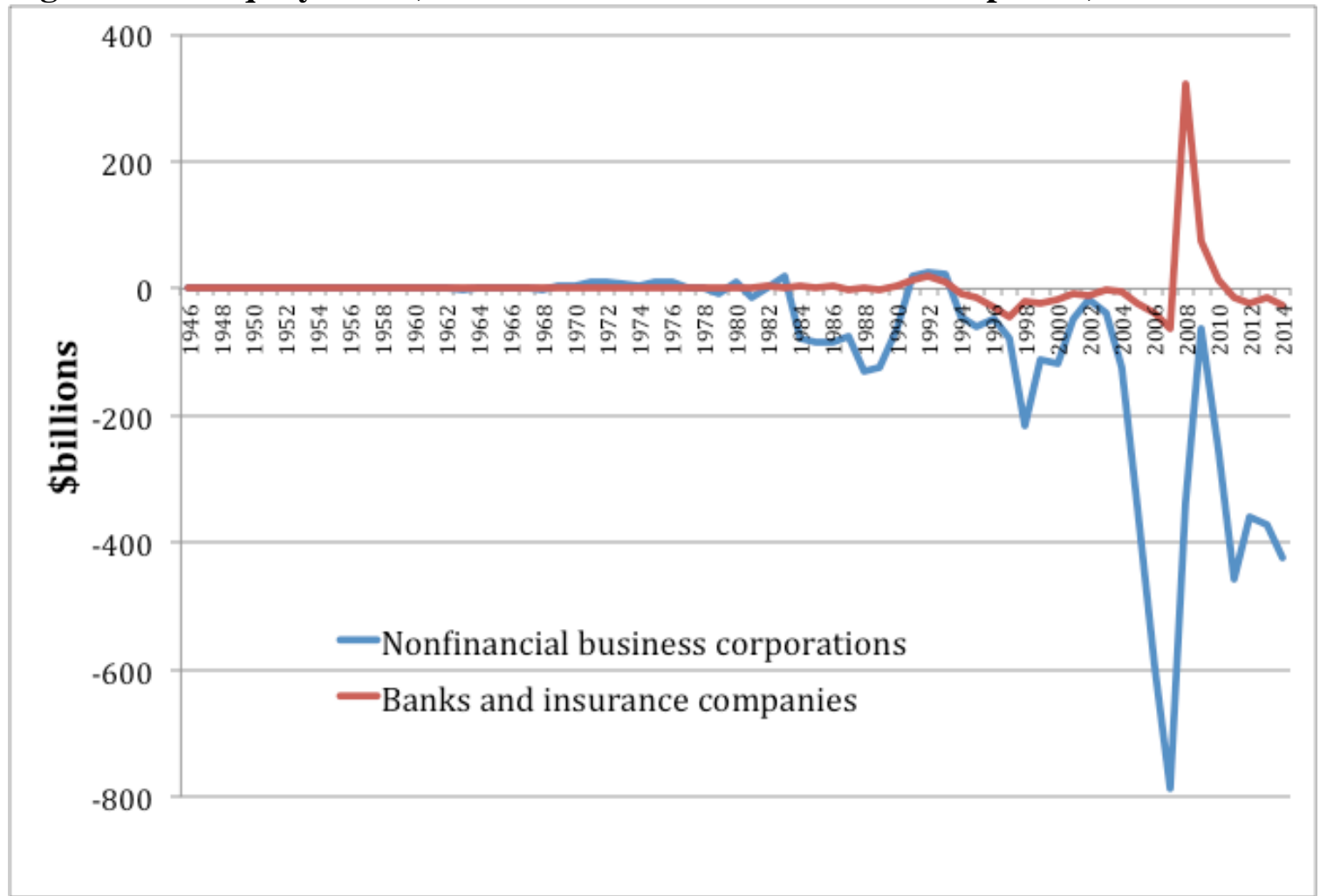

Source: Board of Governors of the Federal Reserve System, Federal Reserve Statistical Release Z.1, "Financial Accounts of the United States: Flow of Funds, Balance Sheets, and Integrated Macroeconomic Accounts," Table F-213, “Corporate Equities”, March 12, 2015.

That buybacks are largely responsible for negative net equity issues is clear from the chart on the evolution of gross repurchases shown in Figure 4. For the 248 companies in the S\&P 500 Index in March 2014 that were publicly listed back to 1981, the buyback payout ratio - that is,

\footnotetext{
${ }^{63}$ Federal Reserve Bank of St. Louis, Federal Reserve Economic Data, "Corporate profits after tax with iva and ccadj: net dividends," at http://research.stlouisfed.org/fred2/series/dividend.

${ }^{64}$ The spike in equity issues for financial corporations in 2009 occurred when they sold stock to the U.S. government in the bailout. The banks that were bailed out had been major repurchasers of their stock in the years before the financial meltdown. See William Lazonick, "Everyone is paying the price for share buy-backs," Financial Times, September 26, 2008, p. 25; William Lazonick, “The buyback boondoggle,” BusinessWeek, August 24 \& 31, 2009, p. 96.
} 
repurchases as a proportion of net income - was less than 5\% in 1981-1983 but 42\% in 20112013, with a three-year peak of 68\% in 2006-2008. From 1981 to 1985, 1994 to 1999, and 2003 to 2008 , the proportion of net income devoted to buybacks by these 248 companies moved up sharply. In 2007, on the eve of the financial crisis, profits of these 248 companies totaled $\$ 478$ billion, with $72 \%$ (or $\$ 345$ billion) used to do buybacks. In that year, these companies also distributed $\$ 187$ billion as dividends, making the total payout ratio $110 \%$.

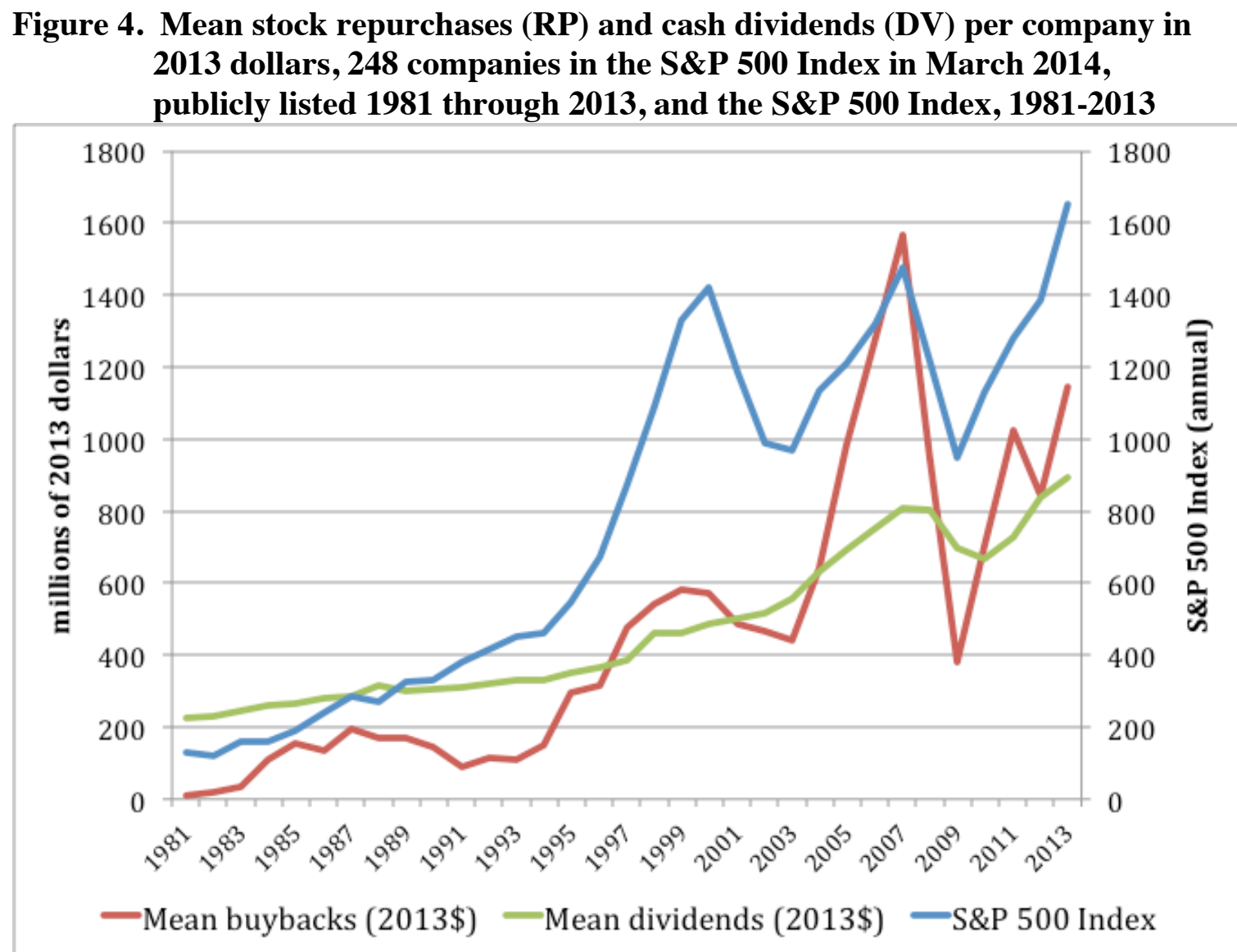

Source: Standard and Poor's Compustat database, corrected from 10-K filings by Mustafa Erdem Sakinç of The Academic-Industry Research Network.

By decade, for 1984-1993, 1994-2003, and 2004-2013, total distributions to shareholders of these 248 companies were $79 \%, 79 \%$, and $84 \%$ respectively, with the proportion of net income devoted to buybacks rising from $25 \%$ to $37 \%$ to $47 \%$. High total payout ratios among major U.S corporations, therefore, are not new, but over the past decade buybacks have predominated in distributions to shareholders. With the profits of the 248 companies soaring, both buybacks and dividends moved up sharply in 2011-2013, as the stock market recovered from the financial crisis, for a total payout ratio of $76 \%$, with, as mentioned above, a substantial amount of these corporation's undistributed profits being held abroad, sheltered from U.S. corporate taxation. ${ }^{65}$

In his 1999 letter to Berkshire Hathaway shareholders, Warren Buffett argued that buybacks could be beneficial to the "continuing shareholder" when done at below "intrinsic value", when

${ }^{65}$ See ISI “Accounting and Tax Research: Cash \& Earnings Parked Overseas.” 
all shareholders "have been supplied all the information they need for estimating that value.",66 These types of repurchases are done as tender offers in which the company announces its intention to repurchase shares at a stipulated price. The vast majority of buybacks done since the mid-1980s, however, have been open-market repurchases in which neither public shareholders nor the Securities and Exchange Commission (SEC), the federal government agency that is supposed to regulate the stock market, have information on the actual days on which top corporate executives have decided to repurchase the company's stock. Only the top executives of the repurchasing company know the timing of the buybacks, creating the possibility that these executives might trade for their own benefit on this valuable inside information.

\section{c) SEC sanctions stock-market manipulation}

On November 17, 1982, the SEC promulgated Rule 10b-18, which gives a company a safe harbor against manipulation charges in doing open-market repurchases. ${ }^{67}$ The safe harbor states that a company will not be charged with manipulation if, among other things, its buybacks on any single day are no more than $25 \%$ of the previous four weeks' average daily trading volume (ADTV). Under Rule 10b-18, moreover, there is no presumption of manipulation should the corporation's repurchases exceed the $25 \%$ ADTV limit. ${ }^{68}$

Rule 10b-18 covers only open-market repurchases, which have been estimated to be at least $90 \%$ of all buybacks, because it is in the open market that undetected stock-price manipulation can most easily occur. Private, off-market transactions such as tender offers are not regulated under the Rule. In 1982 the SEC also excluded "block trades" (defined as at or above $\$ 200,000$ in value or numbering at least 5,000 shares with a minimum value of $\$ 50,000$ ) from the $25 \%$ ADTV calculation, apparently because in the early 1980s block trades, although done on the open market, were viewed as exceptional. In a revision of Rule 10b-18 in 2003, however, the SEC included most block trades in the $25 \%$ ADTV calculation. ${ }^{69}$

If a company wants to do open-market repurchases under the Rule 10b-18 safe harbor, it announces a stock repurchase program that has been approved by its board of directors. But Rule 10b-18 does not require disclosure of the particular days on which top corporate executives instruct the company's broker to execute actual buybacks. In its lack of disclosure, its $25 \%$ safe harbor limit, and the absence of a presumption of manipulation even when the $25 \%$ limit is exceeded, Rule 10b-18 is highly permissive of, and even encourages, stock buybacks.

\footnotetext{
${ }^{66}$ Warren Buffett, "Letter to the shareholders of Berkshire Hathaway, Inc.," at http://www.berkshirehathaway.com/letters/1999.html.

67 Securities and Exchange Commission, "Purchases of Certain Equity Securities by the Issuer and Others; Adoption of Safe Harbor," November 17, 1982, Federal Register, Rules and Regulations, 47, 228, November 26, 1982: 53333-53341.

$68 \mathrm{http} / / /$ www.sec.gov/divisions/marketreg/r10b18faq0504.htm. For the safe harbor to be in effect, Rule $10 \mathrm{~b}-18$ also requires that the company refrain from doing buybacks at the beginning and end of the trading day, and that it do all the buybacks through one broker only.

${ }^{69}$ Securities and Exchange Commission, "Purchases of Certain Equity Securities by the Issuer and Others," (November 10, 2003), Federal Register, Rules and Regulations, 68, 221, November 17, 2003: 64952-64976. In response to comments on the proposed amendments to Rule 10b-18 that expressed concern that the elimination of the block exception would have an adverse impact on issuers with moderate or low ADTV that relied mainly on block purchases to implement their repurchase programs, the SEC amendment permitted a company to do one block trade per week that would remain an exception to the $25 \%$ ADTV calculation so long as no other repurchases were made on that day.
} 
In a 1984 article, "Issuer Repurchases", Lloyd H. Feller, a former associate director of the SEC's Division of Market Regulation, and Mary Chamberlin, the then-current deputy chief counsel of that Division, called Rule 10b-18 a "regulatory about-face" from previous SEC views on the detection and prevention of manipulation through open-market repurchases. ${ }^{70}$ Since the SEC's inception as a result of the Securities Exchange Act of 1934, the regulatory agency had sought to prevent stock-price manipulation by insiders and to require companies to disclose all material information to all stock-market investors. In 1955 the SEC adopted Rule 10b-6 to try to prevent an issuing company from manipulating its stock-price during a distribution of its stock, such as during a public stock offering or a merger-and-acquisition deal, or when it had convertible bonds or warrants outstanding. In the $1960 \mathrm{~s}$, the "go-go years" of conglomeration and takeovers, ${ }^{71}$ the SEC sought to extend this anti-manipulative regulation to open-market repurchases more generally, and not just when a company had a distribution in process.

The result was Rule 13e-2, which emerged out of the Williams Act of 1968 (amending the Securities Exchange Act to require disclosure of information in cash tender offers) and made its first appearance in 1969. Rule 13e-2 was proposed, but never passed in 1970, 1973, and 1980. It emphasized disclosure of full information to investors to maintain the integrity of the stock market. In sharp contrast to Rule 10b-18, which in the "regulatory about-face" was adopted in 1982, Rule 13e-2 would have put a $15 \%$ ADTV limit on open-market repurchases, required disclosure of the days on which buybacks were actually done, and have presumed that a company was manipulating the market if it exceeded the $15 \%$ ADTV limit. Whereas Rule $13 \mathrm{e}-2$ proposed regulation of stock-price manipulation, without by any means banning open-market repurchases, Rule 10b-18 in effect gave corporations license to use open-market repurchases to manipulate the market. ${ }^{72}$

This regulatory reversal resulted from the 1980 election of Ronald Reagan as U.S. President on a platform of government deregulation and his appointment in 1981 of John Shad, vice-chairman of the stock brokerage firm E. F. Hutton, to head the SEC. Shad had been the first Wall Street executive to back Reagan for president, and had served as head of fundraising in New York State for the Reagan campaign. ${ }^{73}$ Not since Joseph Kennedy had been the inaugural chair of the SEC in 1934-1935 had a Wall Street executive led the agency.

A Wall Street Journal article on the adoption of Rule 10b-18 noted that " $[\mathrm{t}]$ he new, deregulationminded commission, with its 3-2 majority of Reagan appointees, has been revamping many SEC policies." It went on to say that Shad hoped that buybacks would help to fuel increases in stock prices, and thus be beneficial to shareholders. The longest-serving SEC commissioner, John Evans, appointed by President Nixon in 1973, expressed concern that Rule 10b-18 represented deregulation of buybacks that could result in market manipulation. ${ }^{74}$ In the end, however, Evans agreed to make the adoption of Rule 10b-18 unanimous.

\footnotetext{
${ }^{70}$ Lloyd H. Feller and Mary Chamberlin, "Issuer Repurchases," Review of Securities Regulation, 17, 1, 1984: 993-998.

71 John Brooks, The Go-Go Years, Weybright and Talley, 1973.

72 See Douglas O. Cook, Laurie Krigman, and J. Chris Leach, “An Analysis of SEC Guidelines for Executing Open Market Repurchases, “ Journal of Business, 76, 2, 2003: 289-315.

${ }^{73}$ See Jeff Gerth, "Shad of S.E.C. favors bright corporate image," New York Times, August 3, 1981, p. D1.

${ }^{74}$ Richard L. Hudson, "SEC eases way for repurchase of firms' stock," Wall Street Journal, November 10, 1982, p. 2.
} 
The 2003 amendment to Rule 10b-18 included block trades within the $25 \%$ safe harbor because, as the SEC stated in its release, "during the late 1990s, it was reported that many companies were spending more than half their net income on massive buyback programs that were intended to boost share prices - often supporting their share price at levels far above where they would otherwise trade." The SEC went on to warn that the unregulated use of block trades in doing buybacks could exacerbate "the potential for manipulative abuse", and "mislead investors about the integrity of the securities trading market as an independent pricing mechanism."."

In seeking to rectify these problems, the 2003 amendment to Rule 10b-18 initiated quarterly reports on stock buybacks. But the SEC still did not require disclosure of the actual days on which buybacks were done so that it would be able to determine, without a special investigation, whether a company had in fact exceeded the $25 \%$ ADTV safe harbor limit. And, given the escalation of buybacks after 2003, it is clear that the 2003 amendment did nothing to bring "the potential for manipulative abuse" under control. For the 248 major U.S. corporations included in Figure 4 above, the repurchase payout ratio for 2004 through 2007 was 56\%, far higher than the 45\% it had been in 1997 through 2000, a period in which the SEC had viewed buybacks as possibly contributing to market manipulation. Compared with 1997-2000, the absolute value of buybacks in inflation-adjusted dollars was 2.1 times higher in 2004-2007 and 1.4 times higher in 2010-2013. I would contend that during these two periods of a surging stock market in the decade after the 2003 amendment to Rule 10b-18 "manipulative abuse" became even worse.

The daily buybacks that are permissible within the 25\% ADTV limit are sufficiently large to enable a company to manipulate its own stock price. Table 1 shows the top ten stock repurchasers for 2004-2013, and the proportions of net income that each company spent on buybacks and dividends over the decade. In most cases, total distributions to shareholders exceeded net income. Assuming that block trades are included in the ADTV calculations, under Rule 10b-18 on July 29, 2014 (for example) Exxon Mobil, by far the biggest stock repurchaser with $\$ 217$ billion in the decade 2004-2013, could buy back up to $\$ 210$ million worth of shares per day without fear of facing manipulation charges. The daily buyback safe-harbor limits for the next nine top repurchasers for 2004-2013 ranged from \$76 million for Hewlett-Packard to \$369 million for Microsoft. Apple Inc., which did \$22.9 billion in buybacks in fiscal 2013 and another $\$ 45.0$ billion in 2014 (after having largely refrained from the practice during the reign of Steve Jobs) could do up to $\$ 1.2$ billion per day while still availing itself of the safe harbor. ${ }^{76}$ Within the limits of the total value of buybacks set by a board-authorized repurchase program, Rule 10b-18 permits open-market repurchases of these manipulative magnitudes to be repeated trading day after trading day.

Over the decade 2004-2013, 454 companies in the S\&P 500 Index in March 2014 that were publicly listed back to 2004 expended $51 \%$ of net income, or $\$ 3.4$ trillion, on stock buybacks and another $35 \%$ of net income on dividends. That left only $14 \%$ of profits available for funding new investment in productive capabilities or passing on profits to a company's employees as increased remuneration, and with much of those profits held abroad (avoiding as we have seen

\footnotetext{
${ }^{75}$ Securities and Exchange Commission, "Purchases of Certain Equity Securities," Nov. 17, 2003, p. 64959.

${ }^{76}$ See William Lazonick, Mariana Mazzucato and Öner Tulum, “Apple's Changing Business Model: What Should the World's Richest Company Do With All Those Profits?" Accounting Forum, 37, 4, 2013: 249-267.
} 
U.S. corporate taxes) and interest rates low many companies have borrowed to do buybacks. ${ }^{77}$ Substantial research carried out under my direction by The Academic-Industry Research Network and the UMass Lowell Center for Industrial Competitiveness has revealed the economic damage caused by these distributions to shareholders at the industry and company levels.

Table 1. Repurchases (RP) and dividends (DV) as percentages of net income (NI), ten largest repurchasers for the decade 2004-2013

\begin{tabular}{|c|l|r|r|r|r|r|}
\hline $\begin{array}{c}\text { Buyback } \\
\text { rank }\end{array}$ & \multicolumn{1}{|c|}{ Company Name } & RP \$b. & DV \$b & $\begin{array}{c}\text { RP/NI } \\
\%\end{array}$ & $\begin{array}{c}\text { DV/NI } \\
\%\end{array}$ & $\begin{array}{c}\text { NI } \\
\text { NI } /\end{array}$ \\
\hline $\mathbf{1}$ & EXXON MOBIL & 217 & 84 & 60 & 23 & $\mathbf{8 4}$ \\
\hline $\mathbf{2}$ & IBM & 116 & 26 & 92 & 21 & $\mathbf{1 1 3}$ \\
\hline $\mathbf{3}$ & MICROSOFT & 113 & 77 & 71 & 48 & $\mathbf{1 1 9}$ \\
\hline $\mathbf{4}$ & CISCO SYSTEMS & 72 & 5 & 103 & 8 & $\mathbf{1 1 0}$ \\
\hline $\mathbf{5}$ & PROCTER \& GAMBLE & 71 & 47 & 71 & 47 & $\mathbf{1 1 8}$ \\
\hline $\mathbf{6}$ & HEWLETT-PACKARD & 65 & 9 & 148 & 20 & $\mathbf{1 6 8}$ \\
\hline $\mathbf{7}$ & WAL-MART STORES & 64 & 40 & 45 & 28 & $\mathbf{7 3}$ \\
\hline $\mathbf{8}$ & PFIZER & 62 & 65 & 67 & 70 & $\mathbf{1 3 7}$ \\
\hline $\mathbf{9}$ & INTEL & 58 & 31 & 70 & 37 & $\mathbf{1 0 7}$ \\
\hline $\mathbf{1 0}$ & GENERAL ELECTRIC & 57 & 87 & 35 & 54 & $\mathbf{8 9}$ \\
\hline
\end{tabular}

Source: Standard and Poor's Compustat database, corrected from company 10-K filings by Mustafa Erdem Sakinç, The Academic-Industry Research Network.

\section{d) The economic damage that buybacks can do}

When, as shown in Table 1 for the ten largest repurchasers in 2004-2013, those who exercise strategic control over resource allocation in the nation's major corporations distribute most or all their companies' earnings to shareholders, we have to question what innovative investment opportunities they are failing to fund. Given the importance of these companies in the industries in which they operate, this type of financial behavior has enormous costs for the performance of the U.S. economy at both the industry level and the company level. Considering the ten largest repurchasers in Table 1, here are three industry examples and three company examples of how stock buybacks harm the economy.

\section{Industries}

Alternative energy. Exxon Mobil spends about $\$ 21$ billion a year on buybacks while receiving U.S. government tax breaks of $\$ 600$ million annually for oil exploration. ${ }^{78}$ It spends virtually no money on alternative energy research. Meanwhile, other companies that want alternative energy expect the U.S. government to fill the gap. In June 2010, the self-styled American Energy Innovation Council (AEIC), made up of current and former heads of Bank of America, Cummins Engine, Du Pont, General Electric, Lockheed Martin, Microsoft, and Xerox as well as John

\footnotetext{
${ }^{77}$ Lazonick, "The Financialization of the U.S. Corporation," pp. 895-896; Steven C. Johnson and Jennifer Ablan, "Rise of shareholder activism gives bondholders headaches," Reuters News, December 13, 2013.

78 Daniel J. Weiss and Seth Hanlon, “Romney’s Tax Plan: Many Happy Returns for Big Oil,” Center for American Progress, July 2012, at http://cdn.americanprogressaction.org/wp-content/uploads/issues/2012/07/pdf/romney_big_oil.pdf.
} 
Doerr, partner in the venture capital firm Kleiner Perkins Caufield \& Byers, put out a plan for "America's Energy Future." ${ }^{79}$ In a press release, Doerr stated,

When our company [Kleiner Perkins] shifted our attention to clean energy, we found the innovation cupboard was close to bare. America has simply neglected to support serious energy innovation. My partners and I found the best fuel cells, the best energy storage, and the best wind technologies were all born outside the United States. Other countries are investing huge amounts in these fields. Without innovation, we cannot build great energy companies. We need to restock the cupboard or be left behind. ${ }^{80}$

The AEIC plan called for the U.S. government to increase annual spending on clean energy innovation from $\$ 5$ billion to $\$ 16$ billion. Yet just two of the AEIC companies, Microsoft and General Electric, together spent $\$ 17.1$ billion annually on buybacks over the decade 2004-2013, while the other five AEIC corporations named above did another $\$ 6.8$ billion annually. AEIC corporate executives want the U.S. taxpayer to fund investment in the development of alternative energy while the companies that they head waste billions of dollars of corporate profits manipulating their stock prices.

Nanotechnology. Intel executives have long lobbied the U.S. government to increase spending on nanotechnology research, arguing, as its then-CEO Craig R. Barrett did in 2005, that "it will take a massive, coordinated U.S. research effort involving academia, industry, and state and federal governments to ensure that America continues to be the world leader in information technology." ${ }^{\text {"1 }}$ Yet from 2001, when the U.S. government launched the National Nanotechnology Initiative (NNI), through 2013, Intel's expenditures on buybacks were almost four times the total NNI budget. Given how much a company such as Intel has benefited from decades of government investment in microelectronics and related fields, one might expect that Intel would use its so-called free cash flow to play a major role in the "massive, coordinated U.S. research effort" of which Barrett spoke rather than waste billions of dollars of corporate profits manipulating its stock price.

Pharmaceutical drugs. US pharmaceutical companies counter the complaint that prescription drugs are at least twice the price in the United States as in any other country with the argument that the profits from these high drug prices permit more R\&D to be done in the United States than elsewhere..$^{82}$ Yet over the past decade there has been a discussion of the "productivity crisis" in drug discovery. ${ }^{83} \mathrm{~A}$ major part of the problem is that leading U.S. pharmaceutical companies

\footnotetext{
${ }^{79}$ AEIC website: http://americanenergyinnovation.org/principals/; John M. Broder, "A call to triple U.S. spending on energy research," New York Times, June 9. 2010, p. B3; Lazonick, "The Financialization of the U.S. Corporation, "pp. 890-891.

${ }^{80}$ American Energy Innovation Council, “American Business Leaders Call for Revolution in Energy Technology Innovation," AEIC press release, June 10, 2010, at http://americanenergy innovation.org/press-release-call-for-revolution-in-energy-techinnovation/.

81 "U.S. could lose race for nanotech leadership, SIA panel says" EDN Network, March 16, 2005, at http://www.edn.com/electronics-news/4326508/U-S-Could-Lose-Race-for-Nanotech-Leadership-SIA-Panel-Says.

${ }^{82}$ William Lazonick and Öner Tulum, "US Biopharmaceutical Finance and the Sustainability of the Biotech Business Model," Research Policy, 40, 9, 2011: 1170-1187.

83 Matt Hopkins and William Lazonick, "Who Invests in the High-Tech Knowledge Base?" Institute for New Economic Thinking Working Group on the Political Economy of Distribution Working Paper No. 6, September 2014 (revised December 2014), at http://ineteconomics.org/research-programs/political-economy-distribution/papers/who-invests-high-tech-knowledgebase, pp. 56-57; William Lazonick, Philip Moss, Hal Salzman, and Öner Tulum, "Skill Development and Sustainable Prosperity: Collective and Cumulative Careers versus Skill-Biased Technical Change," Institute for New Economic Thinking
} 
such as Pfizer and Merck have been spending the last two decades living off their patented drugs, with very little to replace them in the pipeline. For the two decades 1994-2013 Pfizer, no. 51 on the 2014 Fortune 500 list with $\$ 53.8$ billion in revenues, expended $66 \%$ of net income on buybacks and another $60 \%$ on dividends, including, in the decade $2004-2013,60 \%$ on buybacks and $63 \%$ on dividends. Over the two decades, Merck, no. 65 on the 2014 Fortune 500 list with $\$ 44.0$ billion in revenues, distributed $42 \%$ of net income as buybacks and $58 \%$ as dividends, including $35 \%$ as buybacks and $71 \%$ as dividends in 2004-2013. Amgen, the largest independent biopharmaceutical company and no. 154 on the 2014 Fortune 500 list with $\$ 18.7$ billion in revenues, expended $103 \%$ of net income on buybacks and another $7 \%$ on dividends over the two decades 1994-2013, including 100\% on buybacks and 8\% on dividends in the decade 2004-2013. Meanwhile these drug companies are able to avail themselves of the knowledge generated by research funded by the National Institutes of Health, with its annual budgets of $\$ 29$ billion to $\$ 31$ billion in recent years, as well as subsidies and intellectual-property protection under the Orphan Drug Act. ${ }^{84}$ Companies such as Pfizer, Merck, and Amgen are not using high drug prices to conduct more R\&D in the United States. On the contrary, the profits from high drug prices are being used to do buybacks to give short-term boosts to the companies' stock prices and bolster dividend yields to shareholders.

\section{Companies}

International Business Machines (IBM). Until its restructuring in the early 1990s that saw its worldwide employees drop from 374,000 at the end of 1990 to 220,00 at the end of 1994, IBM was a company that touted its "lifelong employment" policy, claiming that it had never laid off anyone involuntarily since 1921. Through the 1980s the norm of a career with one company characterized most established "Old Economy" companies. By 1994, with Louis Gerstner as CEO, IBM had obliterated the system of lifelong employment, and over the next decade every other major Old Economy company followed suit. Meanwhile, focusing on software and services, and shedding its manufacturing capabilities, IBM led the U.S. offshoring movement. By 2008 the company employed 398,000 people, but only 30\% of them were in the United States, down from 52\% in 1996. At that point, IBM ceased publication of data on the number of U.S. employees in its global labor force, and, as it continued to do massive buybacks, also did massive layoffs of North American employees, replacing then with hires in India and other lowwage countries. ${ }^{85}$ In 2011, with its operating earnings per share (EPS) at \$13.44, IBM announced its "2015 EPS Road Map," the objective of which was to reach at least \$20 EPS by the end of $2015 .{ }^{86}$ Along with revenue growth and operating leverage, IBM cited stock repurchases as a driver in achieving its EPS objective. One way in which IBM has been increasing "operating leverage" to boost EPS has been through layoffs of U.S. employees. Another way has been stock buybacks. ${ }^{87}$ From 2010 to 2014 , IBM did $\$ 70.0$ billion in buybacks, equal to $92 \%$ of net income,

Working Group on the Political Economy of Distribution Working Paper No. 7, December 2014, pp. 51-54, at ineteconomics.org/research-programs/political-economy-distribution/papers/skill-development-and-sustainable-prosperity

84 Lazonick and Tulum, "US Biopharmaceutical Finance."

85 Lazonick, Sustainable Prosperity, ch. 3; Lazonick, "The New Economy Business Model".

${ }^{86}$ IBM, "Generating Higher Value at IBM" at www.ibm.com/annualreport/2011/ghv/\#five

87 Heidi Moore, "IBM fires small-town workers for Wall Street numbers," The Guardian, March 2, 2014; See also Nick Summers, "The trouble with IBM," Bloomberg BusinessWeek, May 22, 2014; Steve Denning, "Why IBM is in decline," Forbes, May 30, 2014. In an interview conducted by Justin Fox of Harvard Business Review, former IBM CEO Sam Palmisano in essence states that his major role as the company's top executive was to keep shareholders happy by distributing cash to them: "Managing Investors," Harvard Business Review, June 2014: 80-85. 
including $\$ 13.7$ billion (114\% of net income) in 2014, as it reduced its worldwide employment by 51,620 , or $12 \%$ of its labor force at the end of 2013. In the third quarter of 2014, IBM's EPS was $\$ 14.72$ on an annual basis, over $\$ 5$ shy of its 2015 goal ${ }^{88}$ Apparently the company had not been downsizing and distributing hard enough. In October 2014 IBM announced that it was abandoning the 2015 EPS Road Map. ${ }^{89}$

Hewlett-Packard (HP). As described by founder David Packard in his 1995 book, The HP Way, HP, like IBM, provided stable careers and equitable pay to its employees as a foundation for continuous innovation. ${ }^{90}$ Into the last half of the 1990s, its "HP Way" epitomized a "retain-andreinvest" allocation regime. But in 1999 it spun off its engineering division as Agilent, and then did away with employment security, becoming known as a "hire-and-fire" company that engaged in "employee churn." "From 2004 to 2011, HP did \$61.4 billion in buybacks, equal to $120 \%$ of its net income, along with $\$ 6.8$ billion in dividends. Unlike IBM, however, HP largely failed in its attempt to shift from selling hardware to high-margin software and services. ${ }^{92}$ After spending $\$ 11.0$ billion on buybacks in 2010 and $\$ 10.1$ billion in 2011 , the company took a $\$ 12.7$ billion loss in 2012, in large part because of an $\$ 8.8$ billion write-off of the $\$ 11.7$ billion it had paid for UK-based software company Autonomy just one year before. In both 2013 and 2014 HP had declining revenues as its services business floundered, but restored its profitability by cutting its labor force from 349,600 on October 31, 2011 to 302,000 on October 31, 2014. With another 14,000 layoffs envisioned for fiscal 2015, HP announced its intention to split in two, with one company producing printers and other computer hardware and the other company providing computer-related services. ${ }^{93}$ Meanwhile, even with this restructuring in process, this "downsizeand-distribute" company could not kick the buyback habit. As it incurred huge losses in 2012, HP distributed $\$ 1.6$ billion in buybacks and \$1.0 billion in dividends. In 2013-2014 HP disgorged $65 \%$ of net earnings to shareholders, of which $\$ 4.3$ billion were buybacks and $\$ 2.3$ billion dividends.

Cisco Systems. In the 1990s Cisco Systems, which had been founded in Silicon Valley in 1984 and had gone public in 1990, was the fastest growing company in the world as its captured more than $70 \%$ of the global Internet router market. Using its stock as an acquisition currency, from 1993 through 2000, Cisco did 71 acquisitions for over \$35 billion, of which $98 \%$ was paid in its shares. In March 2000 Cisco had the highest market capitalization in the world, but by September 2001, despite revenues that were 17\% higher in fiscal 2001 than the previous year, Cisco' stock price had fallen to just $14 \%$ of its peak. ${ }^{94}$ At that point Cisco started buying back its stock, and from 2002 through 2014 expended $\$ 89.3$ billion on buybacks, equal to $108 \%$ of its net

${ }^{88}$ Harold Meyerson, "IBM's big blues," Washington Post, October 22, 2014, at www.washingtonpost.com/opinions/haroldmeyerson-ibms-strategy-on-earnings-gives-the-company-the-big-blues/2014/10/22/666ae856-5a23-11e4-bd61346aee66ba29 story.html

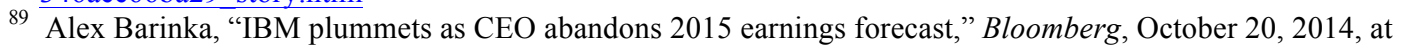
www.bloomberg.com/news/2014-10-20/ibm-abandons-2015-earnings-goal-as-rometty-divests-assets-1-.html

90 David Packard, The HP Way: How Bill Hewlett and I Built Our Company, HarperBusiness, 1995.

${ }^{91}$ Lazonick, Sustainable Prosperity, ch. 3. See David Packard, The HP Way: How Bill Hewlett and I Built Our Company, New York, HarperBusiness, 1995.

92 Rachelle Dragani, "HP rearranges chairs in hopes of propelling turnaround" E-Commerce Times, August 23, 2013, at www.ecommercetimes.com/story/78791.html.

93 Quentin Hardy and David Gelles, "Hewlett-Packard announces breakup plan as technology landscape shifts" New York Times, October 6, 2014, at www.nytimes.com/2014/10/07/business/hewlett-packard-announces-breakup-plan.html

${ }^{94}$ Marie Carpenter, William Lazonick, and Mary O'Sullivan, “The Stock Market and Innovative Capability in the New Economy: The Optical Networking Industry," Industrial and Corporate Change, 12, 5, 2003: 963-1034. 
income. ${ }^{95}$ In the process Cisco eschewed investment in sophisticated communication technologies, despite the fact that it was well positioned to do so at the beginning of the 2000s. Many of Cisco's new products have quickly become commodities, and in recent years the company has engaged in rounds of large-scale layoffs to sustain its buyback habit. In global competition, the relatively young company that made the high-end investments in communication technology that Cisco ignored was Huawei Technologies, a Chinese employeeowned company founded in 1987 that is now challenging Sweden's Ericsson - another company that does not do buybacks - for top spot in the global communication equipment industry. ${ }^{96}$

\section{Maximizing Executive Compensation}

\section{a) Stock-based pay}

In its release on the amendment to Rule $10 \mathrm{~b}-18$ in 2003, the SEC articulated clearly why it needs to get rid of Rule 10b-18. "In summary," wrote the SEC, "Rule 10b-18 is intended to protect issuer repurchases from manipulation charges when the issuer has no special incentive to interfere with the ordinary forces of supply and demand affecting its stock price. Therefore, it is not appropriate for the safe harbor to be available when the issuer has a heightened incentive to manipulate its share price." 97

Yet the stock-based pay of the executives who decide to do repurchases on any given day provides the issuer with "a heightened incentive to manipulate its share price." In recent years average total remuneration of the highest-paid executives was about three times in real terms its level in the early 1990 s when it was already seen as excessive. ${ }^{98}$ As shown in Table 2 , by far the largest components of top executive pay have been stock-based in the forms of gains from exercising stock options and gains from the vesting of stock awards.

From 2006 through 2013, the total remuneration of the 500 highest paid executives in the ExecuComp database averaged \$24.4 million in 2013 dollars, ranging from a low of \$14.4 million in 2009 to a high of $\$ 32.2$ million in 2013. Of these total amounts, the gains from exercising stock options and the vesting of stock awards ranged from $66 \%$ in 2009 to $84 \%$ in 2013, with the combination of salaries and bonuses only accounting for a high of $12 \%$ in 2009 and a low of $5 \%$ in $2013 . .^{99}$

\footnotetext{
95 In 2011 Cisco also began paying dividends, which represented $10 \%$ of net income in $2011,19 \%$ in $2012,33 \%$ in 2013 , and $48 \%$ in 2014.

${ }^{96}$ Bob Bell, Marie Carpenter, Henrik Glimstedt, and William Lazonick, “Cisco’s Evolving Business Model: Do Massive Stock Buybacks Affect Corporate Performance?" paper presented at the Edith Penrose Centenary Conference, SOAS, University of London, November 15, 2014. At theAIRnet, we are currently engaged in studies of both Ericsson and Huawei.

${ }^{97}$ SEC, "Purchases of Certain Equity Securities," Nov. 17, 2003, p. 64965.

98 Graef S. Crystal, In Search of Excess: The Overcompensation of the American Executive, Norton, 1991; William Lazonick, "Taking Stock: How Executive Pay Results in an Inequitable and Unstable Economy," Franklin and Eleanor Roosevelt Institute White Paper, June 5, 2014, at http://www.rooseveltinstitute.org/taking-stock-executive-pay.

99 Standard and Poor's ExecuComp database, with calculations by Matt Hopkins, The Academic-Industry Research Network.
} 
Table 2. Mean total direct compensation of the 500 highest-paid executives named in U.S. corporate proxy statements, and the components of total direct compensation, 2006-2013

\begin{tabular}{|c|c|c|c|c|c|c|c|c|c|}
\hline & & & Per & centage sh & ares of comp & ponents of $t$ & total direct & compensati & ion \\
\hline & $\begin{array}{l}\text { Mean Total } \\
\text { Direct } \\
\text { Comp. } \$ \mathrm{~m} .\end{array}$ & $\begin{array}{l}\text { Mean Total } \\
\text { Direct } \\
\text { Comp. } \\
2013 \$ \mathrm{~m} .\end{array}$ & Salary & Bonus & $\begin{array}{l}\text { Non- } \\
\text { Equity } \\
\text { Incentive } \\
\text { Plan }\end{array}$ & $\begin{array}{l}\text { All Other } \\
\text { Comp }\end{array}$ & $\begin{array}{l}\text { Deferred } \\
\text { Earnings }\end{array}$ & $\begin{array}{l}\text { Realized } \\
\text { Stock } \\
\text { Option } \\
\text { Gains }\end{array}$ & $\begin{array}{l}\text { Realized } \\
\text { Stock } \\
\text { Award } \\
\text { Gains }\end{array}$ \\
\hline 2006 & 27.4 & 30.8 & 3.3 & 7.0 & 7.6 & 5.9 & 0.5 & 58.9 & 16.8 \\
\hline 2007 & 30.0 & 32.9 & 3.0 & 4.1 & 6.9 & 7.6 & 0.1 & 58.8 & 19.6 \\
\hline 2008 & 22.9 & 24.6 & 4.1 & 4.2 & 8.7 & 4.1 & 0.1 & 43.9 & 34.9 \\
\hline 2009 & 14.4 & 15.4 & 7.0 & 4.8 & 14.9 & 7.4 & 0.1 & 39.9 & 25.9 \\
\hline 2010 & 18.5 & 19.5 & 5.5 & 4.8 & 15.0 & 6.2 & 0.1 & 40.3 & 28.1 \\
\hline 2011 & 19.4 & 20.0 & 5.5 & 4.8 & 15.0 & 6.2 & 0.1 & 40.3 & 28.1 \\
\hline 2012 & 30.3 & 30.8 & 3.6 & 2.7 & 8.2 & 3.2 & 0.1 & 41.5 & 40.7 \\
\hline 2013 & 32.2 & 32.2 & 3.3 & 1.9 & 7.6 & 3.5 & 0.1 & 55.4 & 28.2 \\
\hline
\end{tabular}

Source: Standard and Poor's ExecuComp database, with calculations by Matt Hopkins, The Academic-Industry

Research Network

Given the fact that in the United States companies are not required to announce the dates on which they actually do open-market repurchases, there is an opportunity for top executives to do buybacks to benefit themselves. Buybacks can enable companies to hit quarterly EPS targets, with the manipulation invisible to the public. The manipulation of EPS can make executives look good to Wall Street, in some cases offsetting EPS declines that reflect "bad news." 100 And it can also directly pad their pay, as is often the case with stock awards that are contingent on EPS performance. ${ }^{101}$

Moreover, top executives who are privy to the company's repurchasing activity can use this insider information to time their option exercises and stock sales to increase their pay. Indeed, in 1991 the SEC made it easier for top executives to do just that. Until 1991, Section 16(b) of the 1934 Securities Exchange Act prevented top executives from reaping short-swing profits when they exercised their stock options by requiring that they wait at least six months before selling the acquired shares. In 1991, by arguing that a stock option is a derivative, the SEC determined that henceforth the six-month waiting period would begin at the grant date, not the exercise date. Since the option grant date is always at least one year before the option exercise date, this reinterpretation of Section 16(b) means that top executives, as company insiders, can sell the shares acquired from stock options immediately upon exercise and keep the short-swing gains.

With this reinterpretation pending in 1989, a Towers Perrin consultant told the New York Times that the change was "great news for executives because they give insiders much more flexibility in buying and selling stock." The same article noted that the proposed change to Section 16(b) "would provide a dual benefit. Since corporate insiders could immediately sell the stock, they could qualify for loans from brokers that would enable them to exercise stock options without

100 See Lazonick, "The Financialization of the U.S. Corporation,” p. 897, for Amgen's use of buybacks to offset bad news in 2007.

101 See for example Paul Hribar, Nicole Thorne Jenkins, and W. Bruce Johnson, "Repurchases as a Earnings Management Device," Journal of Accounting and Economics, 41, 1-2, 2006: 3-27; Steven Young and Jing Yang, "Stock Repurchases and Executive Compensation Contract Design: The Role of Earnings per Share Performance Conditions," The Accounting Review, 86, 2, 2011: 703-33. 
laying out their own cash. They would also no longer face the risk that the shares might decline in value during the holding period."102 After the Section 16(b) reinterpretation went into effect in May 1991, a compensation consultant was quoted as saying that senior executives "now have an opportunity of making a decision of when to get in and out at the most propitious time."103

Do top executives actually trade on this insider information? We do not know because the SEC does not require that, even after the fact, companies disclose the days on which they have done open-market repurchases. Even with SEC Rule 10b5-1, adopted in 2000 to control such insider trading, top executives can time their option exercises and stock sales to increase their pay - all in the name of "maximizing shareholder value." 104 What we do know is that stock-based pay creates a strong incentive for corporate executives to orient themselves toward downsize-anddistribute rather than retain-and-reinvest. And since the 1980s downsize-and-distribute has been the clear-cut winner in the corporate resource-allocation game.

\section{b) Corporate executives in the top $0.1 \%$}

We also know that stock-based pay has enabled corporates executives to become the most populous members of the top $0.1 \%$ in the U.S. income distribution. Figure 5 displays data for 1916 to 2011 on the income shares of the top $0.1 \%$ of U.S. households, collected from tax returns by Thomas Piketty and Emmanuel Saez. As can be seen, the biggest component of executive pay over the past quarter century has been "salaries," supplemented by spikes in capital gains at the peaks of stock-market booms such as in 2000 and 2007. The "salary" data include, however, substantial stock-based pay, which is not reported as such in tax returns. ${ }^{105}$ Indeed as we have seen from the ExecuComp data in Table 2, as components of total executive compensation, gains from stock options and stock awards dwarf not only salaries but also bonuses.

We can use the ExecuComp database to get an initial idea of the representation of high-paid corporate executives among the top $0.1 \%$ of households in the income distribution. In 2012, the threshold income (excluding capital gains) for inclusion in the top $0.1 \%$ of the income distribution was $\$ 1,549,616 .{ }^{106}$ From the ExecuComp proxy statement data on "named" top executives, in 2012, 4,627 executives had total compensation greater than this threshold amount, with a mean income of $\$ 6,824,000$, of which $31 \%$ was gains from exercising stock options and $37 \%$ gains from vesting of stock awards.

The number of corporate executives who, in 2012, were members of the top $0.1 \%$ club was, however, far higher than 4,627, for two reasons. First, total corporate compensation of the named executives does not include other non-compensation income (from securities, property, fees for sitting on the boards of other corporations, etc.) that would be included in their federal tax returns. If we assume that named executives whose corporate compensation was below the $\$ 1.55$

\footnotetext{
102 Carole Gould, "Shaking up executive compensation," New York Times, April 9, 1989, p. F13.

103 Jan M. Rosen, "New regulations on stock options," New York Times, April 27, 1991, p. 38.

104 See, for example, Jesse Eisinger, "Repeated good fortune in timing of CEO's stock sale," New York Times Dealbook, February 19, 2014, at http://dealbook.nytimes.com/2014/02/19/repeated-good-fortune-in-timing-of-c-e-o-s-stock-sale/

${ }^{105}$ Almost all gains from exercising employee stock options and the vesting of employee stock awards are taxed at the ordinary personal income tax rate, not at the capital gains tax rate, with taxes withheld by the employer at the time that options are exercise or awards vest. Hence these stock-based gains are reported as part of salary income.

${ }^{106} \mathrm{http}$ ://topincomes.parisschoolofeconomics.eu/\#Database: United States, P99.9 income threshold.
} 
million threshold were able to augment that income by $25 \%$ (to pick a plausible number) from other sources, then the number of named executives in the top $0.1 \%$ in 2012 would have been 5,398 .

Figure 5. Share of total U.S. incomes of the top $0.1 \%$ of households in the U.S. income distribution and its components, 1916-2011

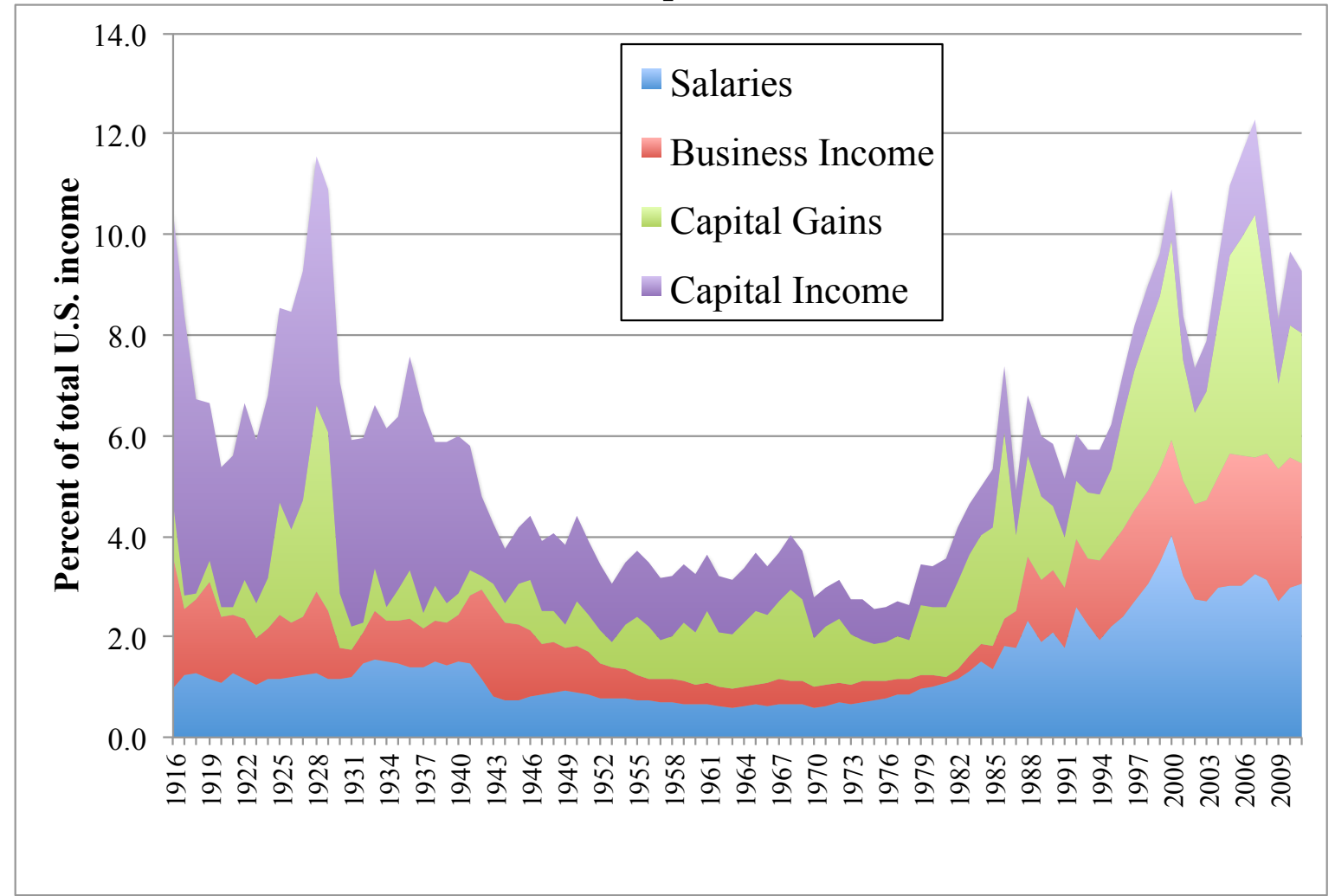

Source: http://topincomes.parisschoolofeconomics.eu/\#Database: United States, Top 0.1\% income composition.

Note: "Salaries" includes compensation from the realized gains on exercising stock options and the vesting of stock awards.

Second, included in the top $0.1 \%$ of the U.S. income distribution were a potentially large, but unknown, number of U.S. corporate executives whose pay was above the $\$ 1.55$ million threshold for the top $0.1 \%$, but who were not named in proxy statements because they were neither the CEO nor one of the four other highest paid in their particular companies. For example, of the highest paid IBM executives in 2012 named in the company's proxy statement, the lowest paid had a total compensation of $\$ 9,052,761$. There were presumably large numbers of other IBM executives whose total compensation was between this amount and the $\$ 1.55$ million threshold for inclusion in the top $0.1 \%$. These "unnamed" executives would have been among the top $0.1 \%$ in the income distribution.

There is another, more direct, method for gauging the representation of corporate executives among the top $0.1 \%$. Federal tax returns include information on a filer's occupation and, through an employer identification number (EIN), the type of business sector that provides the taxpayer with his or her primary employment income. Jon Bakija, Adam Cole and Bradley Heim accessed 
federal tax return data for selected years from 1979 to 2005 to analyze the occupations of federal taxpayers at the top of the U.S. income distribution. They found that "executives, managers, supervisors, and financial professionals account for about $60 \%$ of the top $0.1 \%$ of income earners in recent years, and can account for $70 \%$ of the increase in the share of national income going to the top $0.1 \%$ of the income distribution between 1979 and 2005." 107

For 2005, they found that of taxpayers whose incomes including capital gains placed them in the top $0.1 \%$, executives, managers, and supervisors in non-finance businesses made up $41.3 \%$ of the total, while financial professionals (including management) were another $17.7 \%$. Of the $41.3 \%$ who were non-finance executives, managers or supervisors, $19.8 \%$ were salaried and the rest were in closely held businesses. ${ }^{108}$ Besides the $6.2 \%$ of the top $0.1 \%$ who were "not working or deceased," the next largest occupational groups were lawyers with 5.8\%, real estate with $5.1 \%$, and medical with $4.1 \%$.

The bottom line is that top executives of U.S. business corporations - industrial as well as financial - are very well represented among the top $0.1 \%$ of the U.S. income distribution, with much, and often most, of their compensation income coming from the realized gains from exercising stock options and the vesting of stock awards. When the compensation of top executives is combined with the fact that Wall Street has, since the 1980s, judged the performance of corporations by their quarterly stock-price performance, the importance of stockbased pay in executive compensation gives top executives a powerful personal incentive to boost their companies' stock prices from quarter to quarter. In stock buybacks, these executives have found a potent, and SEC-approved, instrument for stock-market manipulation from which they can personally benefit, even if the stock-price boosts are only temporary. Top executives of U.S. corporations have been given both the incentives and the tools for deciding, as the previously quoted compensation consultant put it, "when to get in and out at the most propitious time."

\section{c) The self-serving ideology of "maximizing shareholder value"}

Legitimizing both stock buybacks and stock-based pay is the economic ideology that business corporations should be run to "maximize shareholder value" (MSV). In the 1970s and 1980s agency theorists trained in the conservative economics tradition of the University of Chicago propounded the theory that a corporation will maximize the efficiency of the economy if it maximizes the value of the company's shares. ${ }^{109}$ The problem, as they saw it, was that the managers of large corporations, in control of the allocation of significant resources, had a tendency, if left to their own devices, to build empires and invest in wasteful projects.

The MSV perspective viewed hostile takeovers, or what more generally became known as "the market for corporate control," as one way in which shareholders could force managers to stop wasting corporate resources and distribute cash to shareholders. Agency theorists had a stockmarket carrot to go along with this stock-market stick. They argued that by making stock-based

\footnotetext{
${ }^{107}$ Jon Bakija, Adam Cole, and Bradley T. Heim, "Jobs and Income Growth of Top Earners and the Causes of Changing Income Inequality: Evidence from U.S. Tax Return Data," working paper, April, 2012, at

https:/web.williams.edu/Economics/wp/BakijaColeHeimJobsIncomeGrowthTopEarners.pdf. The quote is from the paper's abstract. I am grateful to Thomas Piketty for bringing this study to my attention.

108 Bakija et al., "Jobs and income growth," p. 38.

${ }^{109}$ See Michael C. Jensen, "Agency Costs of Free Cash Flow, Corporate Finance, and Takeovers," American Economic Review, 76, 2, 1986: 323-329.
} 
pay a major proportion of executive compensation, the incentives of corporate managers in the allocation of resources could be aligned with those of public shareholders. ${ }^{110}$ Only by disgorging the corporation's "free cash flow" to shareholders, the MSV proponents contended, would the economy's resources be allocated to their most efficient uses. The money from the corporate coffers could be distributed to shareholders in the forms of cash dividends and stock repurchases. In short, by "maximizing shareholder value," corporate resource allocation would result in the best possible performance of the economy as a whole.

The MSV argument is that, of all participants in the business corporation, shareholders are the only economic actors who make productive contributions without a guaranteed return. All other participants such as creditors, workers, suppliers, and distributors allegedly receive a marketdetermined price for the goods or services that they render to the corporation, and hence take no risk of whether the company makes or loses money. On this assumption, only shareholders have an economically justifiable claim to the "residual" that is left over after the company has paid all other stakeholders their guaranteed contractual claims for their productive contributions to the firm.

By the MSV argument, shareholders are the only stakeholders who need to be incentivized to bear the risk of investing in productive resources that may result in superior economic performance. As the only "residual claimants," moreover, shareholders are the only stakeholders who have an interest in monitoring managers to ensure that they allocate resources efficiently. Furthermore, by buying and selling corporate shares on the stock market, public shareholders, it is argued, can directly reallocate resources to more efficient uses.

The fundamental problem with MSV lies in the assumption that shareholders are the only corporate participants who bear risk. Taxpayers through government agencies and workers through the firms that employ them make risky investments in productive capabilities on a regular basis. From this perspective, both the state and labor have "residual claimant" status; that is, an economic claim on the distribution of profits.

Through government investments and subsidies, taxpayers regularly provide productive resources to companies without a guaranteed return. As an important example, but only one of many, in 2013 the annual budget of the National Institutes of Health (NIH) was $\$ 29.3$ billion, with a total NIH investment from 1938 through 2013 of $\$ 875$ billion in 2013 dollars. ${ }^{111}$ As risk bearers, taxpayers have a claim on corporate profits if and when they are generated. But these profits, and hence the tax revenues on them, are not guaranteed. Through the tax system, governments, representing taxpayers in general, seek to extract this return from corporations and individuals that reap the rewards of government spending. Through the political process, however, tax rates and tax revenues are subject to change, thus creating further uncertainty of the returns to taxpayers that will actually accrue when tax dollars are used to invest in the economy.

\footnotetext{
110 Michal C, Jensen and Kevin J. Murphy, "Performance Pay and Top Management Incentives,” Journal of Political Economy, 98, 2, 1990: 225-264.

111 Lazonick and Tulum, "US Biopharmaceutical Finance.” National Institutes of Health website, at http://www.nih.gov/about/almanac/appropriations/index.htm
} 
Workers regularly make productive contributions to the companies for which they work through the exercise of skill and effort beyond those levels required to lay claim to their current pay, but without guaranteed returns. ${ }^{112}$ Any employer who is seeking to generate higher quality, lower cost products knows the profound productivity difference between employees who just punch the clock to get their daily pay and those who engage in learning to make productive contributions through which they can build their careers and thereby reap future returns in work and in retirement. Yet these careers and the returns that they can generate are not guaranteed.

As risk bearers, therefore, taxpayers whose money supports business enterprises and workers whose efforts generate productivity improvements have economic claims on corporate profits if and when they occur. MSV ignores the risk-reward relation for these two types of economic actors in the operation and performance of business corporations. Instead it erroneously assumes that only shareholders are residual claimants. ${ }^{113}$

The irony of MSV is that the public shareholders whom it holds up as the only risk bearers typically never invest in the value-creating capabilities of the company at all. Rather they invest in outstanding shares in the hope that they will rise in price on the market. And, following the directives of MSV, a prime way in which corporate executives fuel this hope is by disgorging the so-called free cash flow in the forms of not only dividends but even more importantly buybacks.

\section{Exploding Executive Pay, Eroding American Prosperity}

I have argued that the increasing concentration of income at the top of the distribution is both cause and effect of the disappearance of middle-class jobs over the past three decades. It is a cause of the loss of middle-class jobs because of the incentives that stock-based pay gives to top corporate executives to downsize-and-distribute rather than retain-and-reinvest. It is an effect of the disappearance of middle-class jobs because of the trillions of dollars of "free" corporate cash that through distributions to shareholders flows, in particular, into the compensation packages of top executives and, more generally, into the coffers of financial interests who then seek to extract yet higher gains through corporate distributions. Investments in productive resources that can generate competitive industrial products require "patient," not "impatient," finance. ${ }^{114}$ And when finance is patient, the gains to generating competitive products tend to go to employees in the forms of pay increases and promotions, not to shareholders in the forms of higher dividends and massive stock buybacks. ${ }^{115}$

The analysis that I have provided calls into question the main explanation propounded by labor economists for growing income inequality, namely skill-biased technical change (SBTC). The SBTC argument is that the machine technologies made possible by the computer revolution have automated away the relatively lower-level skills that high-school-educated workers provided to the production process coming into the 1980s while creating new demands for the higher-level skills of college-educated workers. SBTC, so the argument goes, decreases the demand for high-

112 Lazonick, Competitive Advantage on the Shop Floor; Lazonick, "Innovative Business Models".

113 Lazonick, "Innovative Enterprise and Shareholder Value".

114 William Lazonick, "Patient capital is a virtue," FT Alphaville, July 24, 2014, at http://ftalphaville.ft.com/2014/07/24/1906762/patient-capital-is-a-virtue/.

115 Lazonick, Sustainable Prosperity; Lazonick "Innovative Business Models"; William Lazonick, "The Chandlerian Corporation and the Theory of Innovative Enterprise," Industrial and Corporate Change, 19, 2, 2010: 317-349. 
school-educated members of the labor force and increases the demand for college-educated members, thus increasing the wage premium for higher education levels. In the presence of SBTC, a polarization of the U.S. labor market occurs. ${ }^{116}$

SBTC was first put forward at the end of the 1980s in an attempt to explain the loss of bluecollar manufacturing jobs during that decade, and the widening premium to a college education. It is clear that in the 1980s the microelectronics revolution greatly increased the demand for college-educated workers with computer-related skills. But the notion that it was SBTC that threw blue-collar employees out of work in the 1980s has little empirical basis. Rather, from the beginning of the decade it was Japanese competition that precipitated the plant closings that became endemic in the United States, resulting in the transformation of shop-floor employment relations that I have summarized as rationalization. Instead of confronting the new competition by upgrading the knowledge and capabilities of blue-collar workers through a strategy of retainand-reinvest, increasing numbers of senior executives of established U.S. corporations imbibed the new ideology that corporations should be run to maximize shareholder value - an ideology that legitimized downsize-and-distribute.

As for "skill-biased" technologies, in the 1980s and beyond it was in Japan, with its focus on retain-and-reinvest, not the United States, with its new creed of downsize-and-distribute, that emerged as the world leader in factory automation in the forms of flexible manufacturing systems using computer numerical control (CNC) machines and robotics. Both the development and adoption of flexible manufacturing depended on the existence of a blue-collar labor force with a high degree of employment security as well as a high level of integration into their companies' organizational learning processes, two key characteristics of Japanese employment relations. Japanese production workers, virtually all of them with only high-school educations, were much more willing and much more able than their American counterparts to cooperate with engineers in their companies in the development and utilization of flexible manufacturing systems. $^{117}$

As a result Japan, not the United States, became the world leader in factory automation, a position that it still holds by a wide margin. ${ }^{118}$ In the new digital age, U.S.-style rationalization reflected a weakness, not strength, of U.S. manufacturing, especially when the elimination of previously well-paid blue-collar jobs transformed from a reaction to formidable Japanese competition to a finance-driven quest for higher profits in the name of MSV. Legitimized by this destructive ideology, U.S. corporate executives terminated millions of previously well-paid and stable blue-collar jobs without bearing any responsibility for reinvesting corporate profits to help create new middle-class employment opportunities for an upgraded blue-collar labor force. Rather, invoking MSV ideology, these corporations turned to using billions, and in aggregate trillions, of dollars to manipulate their companies' stock prices.

If the proponents of SBTC misunderstand the rationalization movement of the 1980s, they completely ignore the marketization of U.S. employment relations that occurred from the early

\footnotetext{
${ }^{116}$ David H, Autor, Lawrence F, Katz, and Melissa S. Kearney, "The Polarization of the U.S. Labor Market," American Economic Review, 96, 2, 2006: 189-194.

117 Lazonick, "Organizational Learning."

118 See the website of the International Federation of Robotics, at http://www.ifr.org/industrial-robots/statistics/
} 
1990s. The shift from proprietary technology systems to open technology systems associated with the rise of the New Economy business model represented a pronounced "skill-bias" that favored younger employees over older employees among the college educated. As we have seen, IBM, which among the Old Economy companies led the move to open systems, abruptly and dramatically ended its decades-long system of lifelong employment in the early 1990s. After that, other Old Economy companies followed suit, and by the end of the 1990s the previous norm of a career with one company had all but disappeared. ${ }^{119}$

In the jobless recovery subsequent to the "white-collar" recession of 1990-1991, earnings of college-educated workers stagnated. At the beginning of 1996, AT\&T announced that as part of its planned spinoff of Lucent Technologies and NCR, it would lay off 40,000 employees, most of them middle managers. ${ }^{120}$ For the following months, the media ruminated on "the downsizing of America," including a seven-part series of front-page articles in the New York Times, subsequently collected into a book. ${ }^{121}$

Over the course of 1996, however, talk of downsizing disappeared as the initial surge of what would become the Internet (or New Economy) boom became evident. In December 1996 Fed chairman Alan Greenspan shifted the focus of concern from labor to capital, asking whether "irrational exuberance" in the booming financial markets might be setting the stage for "unexpected and prolonged contractions," as had indeed happened in Japan. ${ }^{122}$ As it turned out, there was a lot of "irrational exuberance" left in the U.S. economy, as the New Economy stockmarket boom swept the nation for the next three-plus years. ${ }^{123}$

During the boom of 1997-2000, wages rose rapidly, especially for college-educated members of the U.S. labor force. For substantial numbers of high-tech employees, this run-up in wages reflected the rise of the New Economy business model, with its broad-based stock option plans that, as we have seen, had functioned since the 1970s to lure professional, technical, and administrative personnel from secure career employment in Old Economy companies to insecure employment in New Economy startups.

The substantial impacts of broad-based employee stock options on changes in earnings are visible in Figure 6, which shows real wages (in 2000 dollars) from 1994 to 2012 for U.S. employees at companies engaged in semiconductors, software publishing, computer programming, and computer system design. Together in 2000 these four ICT fields employed $1,554,000$ people in the United States, more than double the number in 1994, and a total that would rise by $6.5 \%$ to $1,656,000$ in $2012 .^{124}$

119 See, for example, William Lazonick and Edward March, "The Rise and Demise of Lucent Technologies," Journal of Strategic Management Education, 7, 4, 2011.

120 Abby Goodnough, “A crack in the bedrock," New York Times, January 14, 1996. See also Tim Jones, “Amid uproar about layoffs, AT\&T retreats," Chicago Tribune, March 16, 1996.

121 New York Times, The Downsizing of America, Three Rivers Press, 1996.

122 "Allan Greenspan, Chairman of the Federal Reserve Board, delivers remarks at the American Enterprise Institute dinner," NBC Professional Transcripts, December 5, 1996.

${ }^{123}$ It was in March 2000, at the peak of the Internet boom, that Robert Shiller published his book, Irrational Exuberance, Princeton University Press, 2000.

124 These data are from County Business Patterns Data (SIC \& NAICS), U.S. Census Bureau. http://censtats.census.gov/. I am grateful to Yue Zhang for continually updating these time series as well for calculating the average gains per employee from exercising stock options at the company level, to which I refer below. 
Figure 6. Annual earnings in 2000 dollars of full-time U.S. employees in four hightech fields, 1994-2012

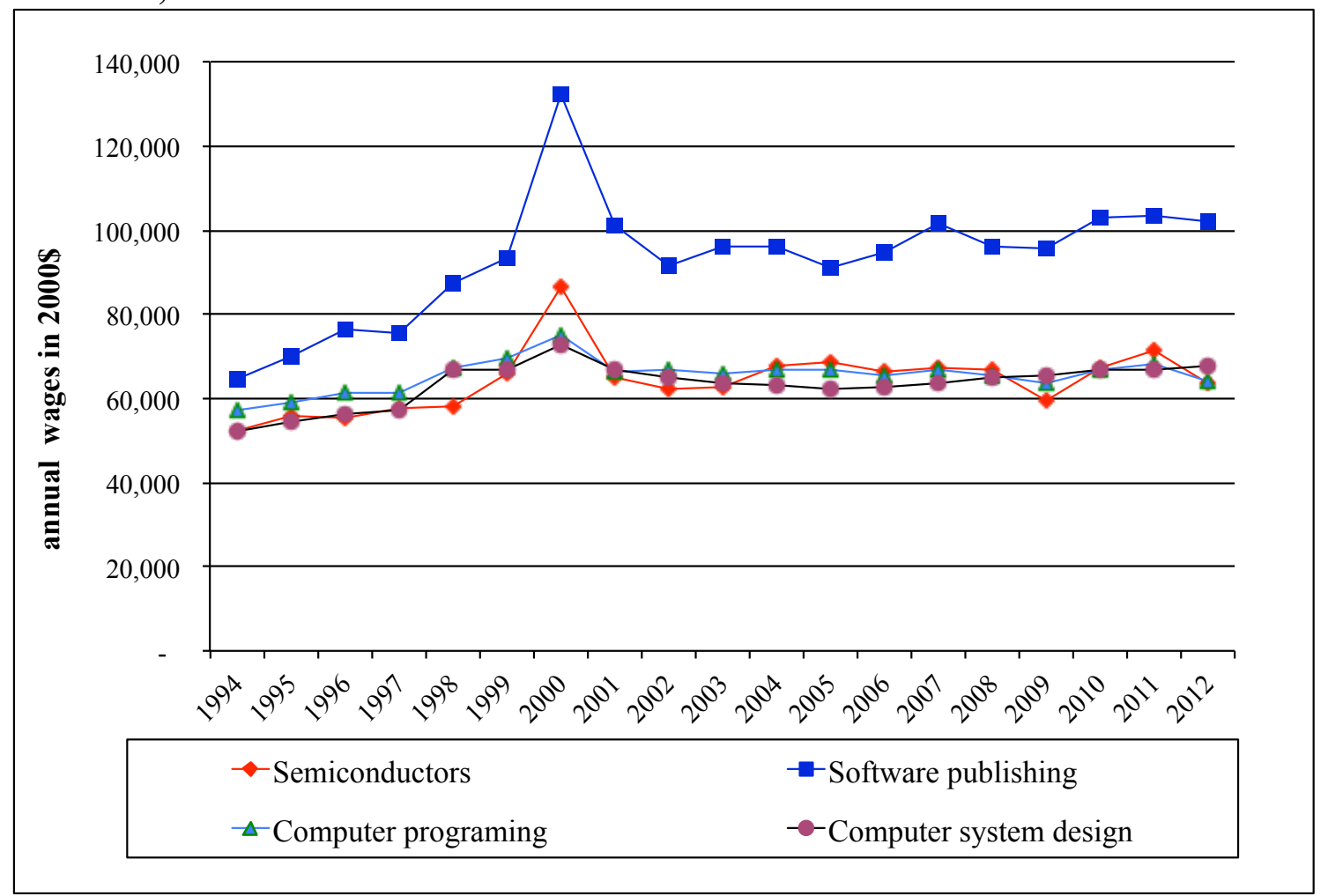

Source: County Business Patterns Data, U.S. Census Bureau. http://censtats.census.gov/.

Note the spikes in earnings in 2000, especially in software publishing in which annual earnings went from $\$ 64,700$ in 1994 to $\$ 75,600$ in 1997 , and then exploded to $\$ 132,100$ in 2000, before falling to $\$ 91,400$ in 2002. Starting from a lower 1994 base, movement in semiconductor earnings was similar to software publishing. Figures 7 and 8, which disaggregate the U.S.-level data into selected high-tech regions, show that the most dramatic income spikes were in software publishing in Washington State, where earnings went from $\$ 112,600$ in 1996 (almost double 1994 earnings) to $\$ 380,000$ in 2000, and in semiconductors in Silicon Valley, where the increase was from $\$ 79,600$ in 1996 to $\$ 156,300$ in 2000 .

The County Business Patterns (CBP) data, on which Figures 6, 7, and 8 are based, do not actually tell us that these spikes are the result of broad-based stock option plans, since all the data are reported simply as earnings. But since 1994 in the notes to their financial statements in $10-\mathrm{K}$ annual filings to the SEC, companies have provided data on their employee stock-option plans, including the total options exercised in the year and the average weighted exercise price. ${ }^{125}$ From this information, we can estimate the average gains per employee from exercising stock options at the company in a given year. (Except for the five executives named in proxy statements for whom individual data on stock option gains are available, we do not know the distribution of these gains across a company's employees.) The most extreme case, and one that corroborates the stock-based interpretation of the remarkable spike in the CBP data for Washington State in Figure 7, was for Microsoft (based in Seattle, Washington) where (excluding the five named

125 See Lazonick, Sustainable Prosperity, pp. 16-28 
executives) the average gains from exercising stock options were $\$ 79,000$ across 19,200 employees in 1996 before soaring to a peak of $\$ 449,100$ across 35,200 employees in 2000, and then falling back to $\$ 80,300$ across 52,800 employees in 2003 .

Figure 7. Annual earnings (2000 dollars), full-time U.S. employees in software publishing, 1994-2012

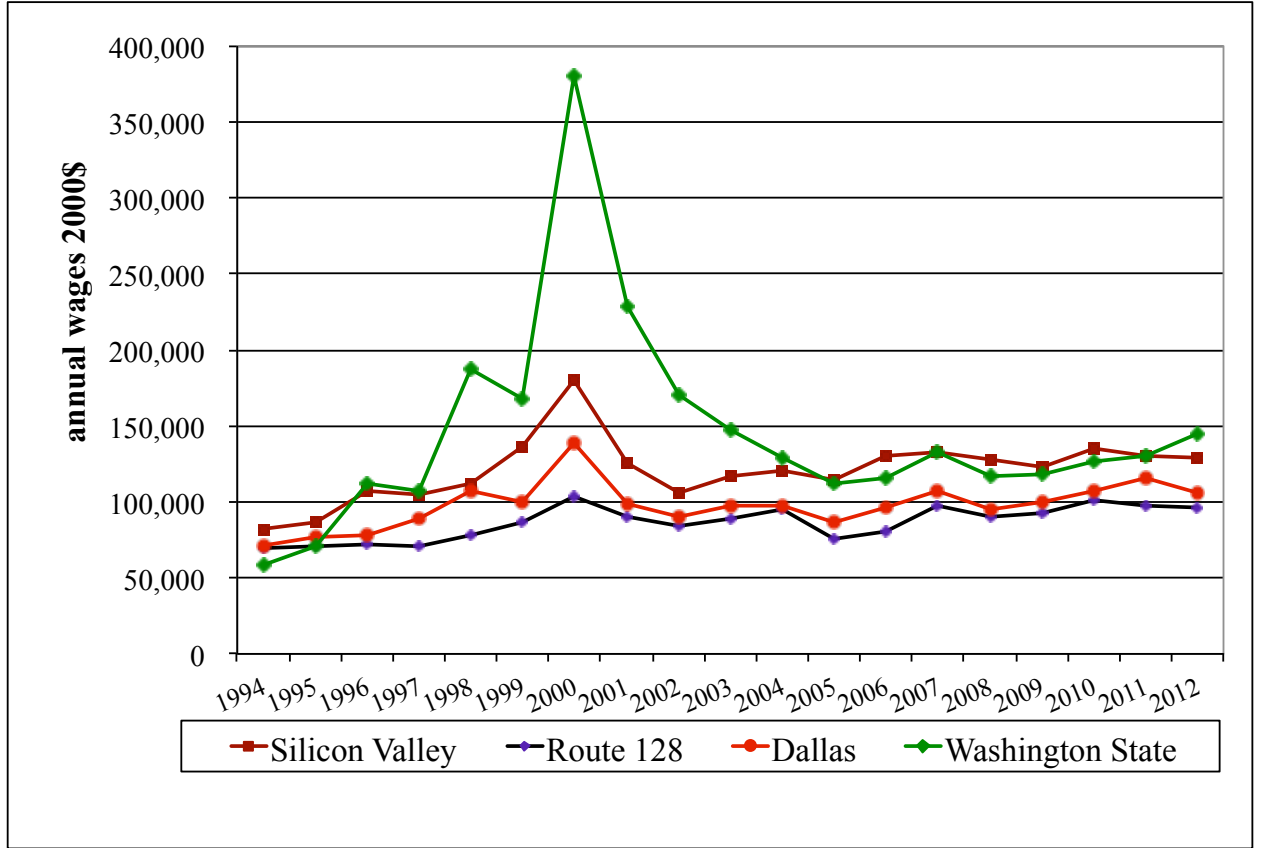

Source: County Business Patterns Data, U.S. Census Bureau. http://censtats.census.gov/.

Figure 8. Annual earnings (2000 dollars), full-time U.S. employees in semiconductors, 1994-2012

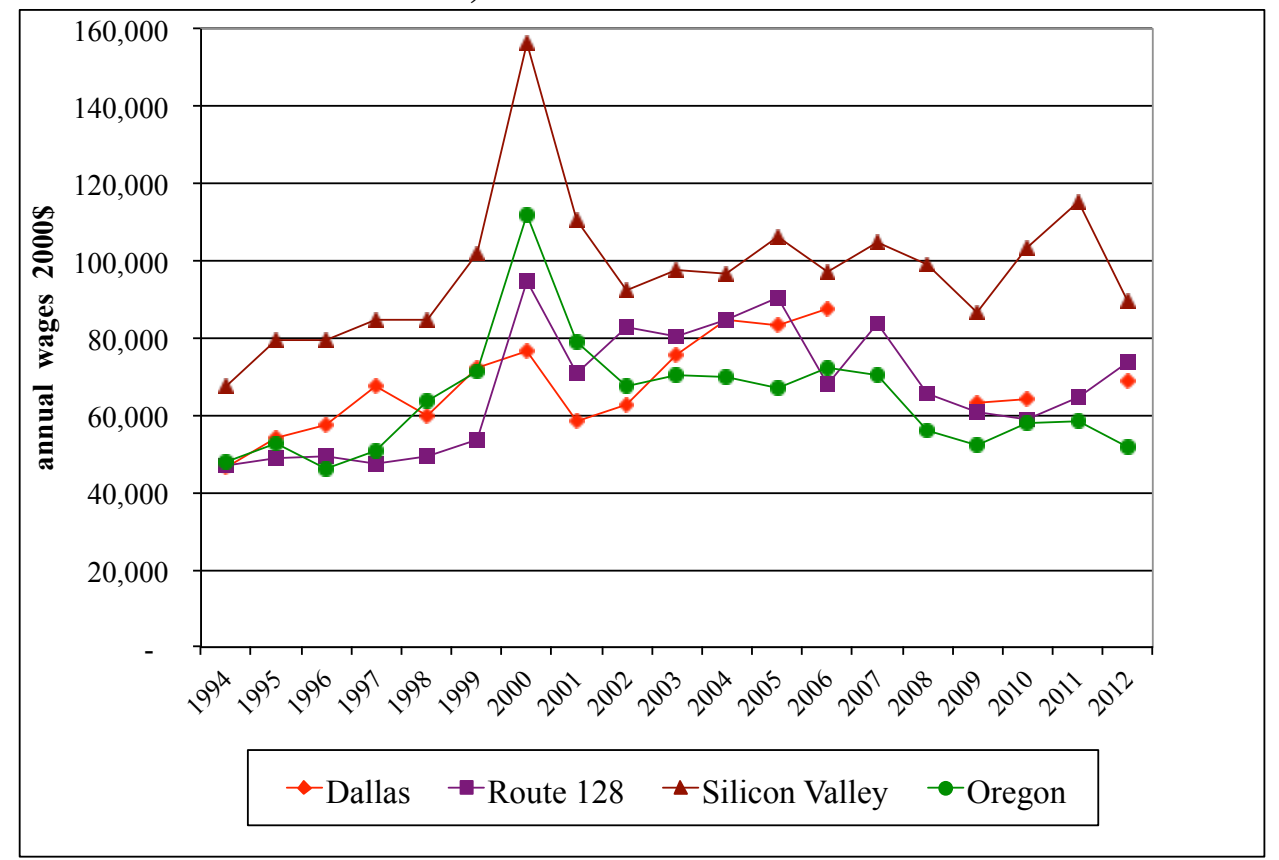

Source: County Business Patterns Data, U.S. Census Bureau. http://censtats.census.gov/. 
These dramatic changes in "wages" cannot be attributed to SBTC. Rather they reflect the fact that in using stock options to lure professional, technical, and administrative personnel from secure employment in established companies to insecure employment in startups, the New Economy companies in effect "outsourced" a substantial portion of the pay of these employees to the wildly volatile stock market. In 2003 Microsoft decided to do away with its stock-option program, in part because of a new ruling from the Financial Accounting Standards Board that requires companies to expense stock-option awards, thus lowering reported earnings with a potentially negative impact on a company's stock price. But the massive gains from stock options going well down into the business organization in the Internet boom and even beyond had already wreaked a different type of havoc on Microsoft, namely the loss of many key employees who had suddenly become extremely rich and left the company to "retire", do a startup, become an angel investor, or take up employment with another company that might offer them even more stock options. In my view, the havoc caused by this mobility of highly remunerated labor was wreaked on Microsoft's organizational learning processes, undermining the ability of the company to engage in innovation in new lines of business. ${ }^{126}$

The marketization of employment relations in the New Economy business model, reflected in the use of broad-based stock option plans, created problems for technological development in the United States more generally even as it facilitated the transfer of U.S. technology abroad as part of the globalization process. In the United States the disruption to organizational learning caused by the movement of high-tech personnel from Old Economy to New Economy companies bears a substantial part of the responsibility for the precipitous decline from the late 1980s of the corporate research labs that had helped to make the United States the world's most technologically advanced economy over the course of the twentieth century. ${ }^{127}$ Proponents of MSV within the top executive ranks and on Wall Street were then better positioned to ask why the company was wasting its money on basic and applied research that might not result in commercial products. Meanwhile "open system" companies that, in large part through mobile high-tech labor, could tap into the ostensibly proprietary technologies of the Old Economy companies could focus on product development to generate, in relatively short order, product revenues.

At a 1993 conference at Harvard Business School that sought to understand the decline of the corporate research lab, Gordon Moore, the co-founder of Intel and its long-time chairman of the board, clearly articulated this relation between basic and applied research done in Old Economy companies and product development done in New Economy companies:

Running with the ideas that big companies can only lope along with has come to be the acknowledged role of the spin-off, or start-up. Note, however, that it is important to distinguish here between exploitation and creation. It is often said that start-ups are better at creating new things. They are not; they are better at exploiting them. Successful startups almost always begin with an idea that has ripened in the research organization of a

\footnotetext{
126 The arguments in this paragraph are based on work-in-progress at the Academic-Industry Research Network. See also William Lazonick, "The New Economy Business Model and the Crisis of US Capitalism," Capitalism and Society, 4, 2 , 2009: article 4.

127 For an elaboration of this argument, see Hopkins and Lazonick, “Who Invests in the High-Tech Knowledge Base?"
} 
large company. Lose the large companies, or research organizations of large companies, and start-ups disappear. ${ }^{128}$

The focus on product development was characteristic of the region where Intel was founded in 1968 and that by the beginning of the 1970s became known as Silicon Valley. In the last half of the 1960s, when this new industrial district spawned dozens of semiconductor start-ups, intense competition, not only from within the United States but also from Japanese chip producers, led virtually every semiconductor company in the United States to seek to cut costs by offshoring assembly and testing operations to lower-wage areas of the world. ${ }^{129}$ The high value and low weight of semiconductor chips meant that, as an alternative to sourcing production in the expanding maquiladora of northern Mexico, transportation costs posed no barrier to offshoring to far-off places such as Hong Kong, Singapore, South Korea, and Taiwan. These Asian nations had much lower wages and far more literate female labor forces than Mexico could offer. From the early 1970s Malaysia also became a location of choice for the offshored activities of U.S. companies engaged in microelectronics. Meanwhile U.S. tariff policy facilitated the offshoring movement: Sections 806.30 and 807 of the Tariff Schedule of the United States permitted goods that had been exported from the United States for foreign assembly to be imported with duty charged only on the value added abroad. ${ }^{130}$

As the offshored Asian factories expanded their employment of female operatives, with at most high-school educations, they also increased the employment of college-educated managers and engineers, while continually upgrading the process technologies in these assembly and testing plants and moving personnel into the fabrication of various electronics components. That is, in the presence of digitization of production processes, the Asian microelectronics industries experienced a complementarity between the employment of high-school-educated and collegeeducated labor to generate higher quality, lower cost products. ${ }^{131}$

Meanwhile, companies such as Motorola, Texas Instruments, Hewlett-Packard, and Intel that were offshoring their more routine work to Asian factories were increasing their employment of college-educated labor at home. Indeed, a New Economy company such as Cisco Systems, that grew to dominate the Internet equipment market in the 1990s while outsourcing all of its manufacturing (be it in the United States or abroad), increased its U.S. employment from 244 in 1990 (the year of its initial public offering) to 27,000 in 2001 , while its rest-of-world employment grew from 10 to $11,000 .^{132}$

128 Gordon E. Moore, "Some Personal Perspectives on Research in the Semiconductor Industry," in Richard Rosenbloom and William Spencer, eds., Engines of Innovation: U.S. Industrial Research at the End of an Era, Harvard Business School Press, 1996, p. 171

129 Y. S. Chang, "The Transfer of Technology: Economics of Offshore Assembly, The Case of the Semiconductor Industry," UNITAR Research Report no. 11. Geneva: United Nations Institute for Training and Research, 1971; Warren E. Davis and Daryl G. Hatano, "The American Semiconductor Industry and the Ascendancy of East Asia," California Management Review, 27, 4, 1985: 128-143; Lazonick, Sustainable Prosperity, ch. 5.

130 Kenneth Flamm, "Internationalization in the Semiconductor Industry," in Joseph Grunwald and Kenneth Flamm, eds., The Global Factory: Foreign Assembly in International Trade, Brookings Institution, 1985: 38-136.

131 Lazonick, Sustainable Prosperity, ch. 5.

132 Cisco Systems annual 10-K filings to the SEC, 1990-2013. The proportion of Cisco labor force in engineering increased from $21 \%$ in 1990 to $28 \%$ in 1996 and to $34 \%$ in 2001 , and since then has ranged from $29 \%$ in 2009 and $36 \%$ in 2002 and 2005 . In 2012 Cisco changed the "engineering" classification to "R\&D". We do not know the distribution of these engineering employees between the United States and rest of world. 
In the period 1990-2001, when Cisco did a relatively small amount of buybacks (21\% of net income in 1995-1997) and paid no dividends, the company added 15,800 more U.S. employees than rest-of-world employees. But from 2002 to 2013, when Cisco expended 107\% of its net income on buybacks and another $7 \%$ on dividends, it added 16,500 more rest-of-world employees than U.S. employees. In 2013 for the first time, rest-of-world employees surpassed US employees, and the trajectory for the future seems clear.

While U.S. companies have been offshoring jobs to Asia, Asians have been coming to the United States for jobs. Since the 1990s vast numbers of college-educated Asians, first and foremost from India, have found employment in the United States under H-1B and L-1 temporary immigrant visa programs. ${ }^{133}$ U.S. companies value these foreign employees not only for their educational backgrounds (the majority have computer-related college degrees, and many of them have acquired further higher education in high-tech fields in the United States before being employed on an H-1B or L-1 visa) but also for their lack of labor mobility within the United States. These employees are beholden to the company that provides them with their visas in industrial sectors where labor mobility can give workers who are citizens or permanent residents considerable bargaining power.

Many employees on H-1B and L-1 visas transition to permanent immigration visas in the United States, but most have gone back to their countries of origin with enhanced education and work experience that are extremely valuable for developing innovative capabilities there. ${ }^{134}$ Indeed, Indian IT companies such as TCS, Infosys, and Wipro have been among the largest users of $\mathrm{H}-$ 1B and L-1 visas as they employ Indians in the United States to acquire more sophisticated capabilities that can be "near-shored" back to India to support the movement of their companies up global value chains. ${ }^{135}$

As with the rationalization and marketization of employment relations, SBTC has little to offer as an explanation of how, why, and in which industries globalization has been eroding middleclass employment opportunities in the United States. ${ }^{136}$ Like all well-trained neoclassical economists, the proponents of SBTC look for the determination of wages in labor markets. People compete for entry-level jobs through labor markets. But the earnings that result in higher standards of living are determined in business organizations, with wages serving as both inducements for contributing to a company's productivity and rewards for prior contributions to a company's profitability. ${ }^{137}$ Rationalization, marketization, and globalization represent

133 Lazonick, Sustainable Prosperity, ch. 5. See the website of Norm Matloff: http://heather.cs.ucdavis.edu/h1b.html.

134 Hira, "Bridge to Immigration or Cheap Temporary Labor?"

135 For the top H-1B visa holders in 29014, see http://www.myvisajobs.com/Reports/2014-H1B-Visa-Sponsor.aspx; for L-1 visas, see Deepak Chitnis, "USCIS to increase scrutiny of Indian IT firms, L-1 visa holders will be under the scanner," The American Bazaar, January 28, 2014, at http://www.americanbazaaronline.com/2014/01/28/uscis-increase-scrutiny-indianfirms-1-1-visa-holders-will-scanner/.

136 For the recognition by SBTC proponents of the impact of Chinese manufacturing on U.S. employment in the 2000 s, see David H. Autor, David Dorn, and Gordon H, Hanson, "The China Syndrome: Local Labor Market Effects of Import Competition in the United States," American Economic Review, 103, 6, 2013: 2121-2068. But this paper offers no analysis of the roles of key organizations - the developmental state and the innovative enterprise - in driving China's remarkable development. For an analytical framework, see William Lazonick and Yin Li, "China's Path to Indigenous Innovation," AIR Working Paper, August 2014 (forthcoming revision).

137 The relation between productivity and earnings was recognized in the "efficiency wage" arguments put forward by a number of economists in the early 1980s. See Janet L. Yellen, "Efficiency Wage Models of Unemployment," American Economic Review, 74, 2, 1984: 200-205; George A. Akerlof and Janet L. Yellen, eds., Efficiency Wage Models of the Labor Market, 
fundamental structural changes in employment relations that disrupted the "Old Economy" relation between productivity and pay as portrayed, toward the beginning of this essay, in Figure 2a. But the financialization of the U.S. corporation, characterized by the shift from retain-andreinvest to downsize-and-distribute, has prevented a reconstruction of employment relations that can provide the foundations for stable and equitable economic growth. Instead since the 1980s the United States has experienced growing income inequality inherent in the growing gap between productivity and wages displayed in Figure $2 b$.

If SBTC has little to say about the reasons for the disappearance of middle-class jobs in the United States, it has even less to say about the concentration of income at the top. ${ }^{138}$ In Capital in the Twenty-First Century, Thomas Piketty criticizes SBTC for "its inability to adequately explain the explosion of very high incomes from labor observed in the United States since 1980." Indeed, notwithstanding the title of his book, Piketty's own explanation for the "explosion of very high incomes" in the United States is not a story of "returns to capital" but rather of "returns to labor." As he says, "let me turn now to the US case, which stands out precisely because it was there that a subclass of 'supermanagers' first emerged over the past several decades." 139 Apparently referring to the work of Bakija, Cole, and Heim that I cited earlier, Piketty states: "Recent research, based on matching declared income on tax returns with corporate compensation records, allows me to state that the vast majority (60 to 70 percent, depending on what definitions one chooses) of the top 0.1 percent of the income hierarchy in 2000-2010 consists of top managers." 140

What then, in Piketty's view, has driven the explosion of executive pay? "Simply put," Piketty tells the reader, "wage inequalities increased rapidly in the United States and Britain because US and British corporations became much more tolerant of extremely generous pay packages after 1970." 141 He sees this growing tolerance for exploding executive pay as the result of changes in "social norms," but he provides no analysis about what these norms are or when, how, and why these norms changed. For example, he makes only an oblique reference in his book to "shareholder value" ideology, a social norm that arose in the 1980s and that, as I have shown, has legitimized the stock-based incomes of the people who control the allocation of resources in U.S. business corporations. ${ }^{142}$

Nor does Piketty raise the possibility that the ways in which top executives have managed to increase their own compensation through their control of the allocation of corporate resources

Cambridge University Press, 1986. This body of research invoked "wage stickiness" as a possible explanation of the stagflation of the 1970s. When stagflation disappeared in the 1980s, the interest in efficiency wages waned.

138 In The Second Machine Age, pp. 151-152, Brynjolfsson and McAfee make the dubious SBTC argument that the high pay of top executives results from the availability of digital technologies that give them the ability to increase their direct oversight of factories throughout the world.

139 Piketty, Capital in the Twenty-First Century, p. 291.

140 Ibid., p. 302.

141 Ibid., p. 332.

142 The closest Piketty comes to acknowledging the existence of shareholder-value ideology as a central social norm of American capitalism in the twenty-first century is in his discussion of the difference between the German stakeholder model and the Anglo-Saxon shareholder model on pp. 145-146 of his book. He states: "The point here is not to idealize this [stakeholder] model of shared social ownership, which has its limits, but simply to note that it can be at least as efficient economically as Anglo-Saxon market capitalism or 'the shareholder model' (in which all power lies in theory with shareholders, although in practice things are always more complex), and especially to observe that the stakeholder model inevitably implies a lower market valuation but not necessarily a lower social valuation.” 
may bear some responsibility for the decline in middle-class employment opportunities. As I have argued in this essay, the ways in which U.S. corporate executives are compensated gives them incentives to allocate corporate resources in ways that have been destructive of employment opportunities for the vast majority of those who seek to work for a living in the United States. The exploding incomes of the top $0.1 \%$ and the erosion of the American middle class are integrally related. For the U.S. economy to achieve stable and equitable growth in the twenty-first century will require an organizational revolution that will have to be far more profound than the managerial revolution that occurred in the opening decades of the twentieth century. And it is the employees at the top of the major corporations, the legatees of that managerial revolution, who now must be brought under control. If not, inequity and instability in the U.S. economy will only get worse. 